Seismic Stratigraphy and Tectonics of Sedimentary Basins around Bornholm Southern Baltic 


\section{Seismic Stratigraphy and Tectonics of Sedimentary Basins around Bornholm Southern Baltic}

BY

OLE VALDEMAR VEJBßK

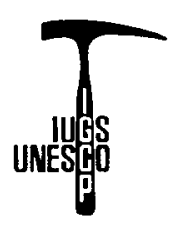

A contribution to the IGCP project no. 86 .

I kommission hos C. A. Reitzels forlag $\cdot$ København 1985 
DGU serie A nr. 8.

ISBN 87-421-0739-3

ISSN 0901-0270

Oplag: 1200

Repro: Carlos Torres og Hertz, Bogtrykkergården

Sats, montage og tryk: Hertz, Bogtrykkergården

Tegning: Henrik Pedersen, Gitte Nicolaisen, Inge Martin-Légene,

Kirsten Andersen, Jannie Knudsen og Eva Melskens

Dato: 1985-10-01

Ole Valdemar Vejbæk, Danmarks Geologiske Undersøgelse,

Thoravej 31, DK-2400 København NV

Redaktion: Knud Binzer

(C) Danmarks Geologiske Undersøgelse,

Thoravej 31, DK-2400 København NV. 
Identification of structural elements in the offshore area around Bornholm has been possible with the use of reflection seismic data. The area straddles the Fennoscandian Borderzone, extending into the Danish Polish Trough.

Major structural depressions are the Rønne Graben, the Arnager Graben (new name), the Christiansø Half-graben and the Hanö Bay Basin. Structural highs are the Christiansø High, the Hammervand High, the Bornholm Gat Uplift, The Dueodde High (new name), the Southern Bornholm High (new name) and Bornholm High.

The Palaeozoic sediments show rapidly increasing thicknesses to the south towards the Caledonian deformation front, and to the east towards the Peribaltic Syneclise. The present distribution of thick Palaeozoic sediments is however primarily a result of Late Palaeozoic - Early Mesozoic erosion. Occurences of Triassic, Jurassic and Lower Cretaceous sediments are primarily restricted to graben areas. These were generated in a Late Carboniferous Early Permian tension dominated right-lateral wrench fault system parallel to the Tornquist line. The Mesozoic sediments of the above mentioned ages were deposited in expanding basins interrupted by tectonic activity, which resulted in renewed restriction of sediments to graben areas accompanied by erosion on structural highs. Late Jurassic and Late Early Cretaceous tectonic events are identified. The most spectacular tectonic event is of an Early Tertiary age. The Rønne Graben and the Arnager Graben were subjected to compression in a right lateral fault system during this phase, and were subsequently uplifted and erosion occured accompanied by reverse faulting and minor folding.
The area studied is in a broad sense a part of the Fennoscandian Border Zone, which continues both in a northwesterly direction and in a southeasterly direction. The regional structures depicted in fig. 1 were identified on the basis of gravimetric, magnetic and primarily, seismic data. The basement is divided into several NW-SE elongated fault blocks. The northeastern-most fault of this system separates the Christiansø High from the Hanö Bay Basin. These major blocks are generally gently tilted with a SE dip,- best seen in the case of the Christiansø High. This dip is opposit to the general dip of some of the major blocks of Scania (for instance the Romeleås High). The general picture is confused by intense faulting within the blocks and by major N-S to NNESSW trending faults, which among others delineate the major Rønne Graben and a minor parallel graben (here named the Arnager graben), that transects the Southern Bornholm High and separates this from the edge of the Baltic Depression. Faults of the same direction do also divide the Christiansø High into several elements, and offset the individual elements in a northeasterly direction when viewed from the west to the east.

These structures are produced by a number of separate tectonic events, that resulted in pronounced fault activity in this boundary area between the Fennoscandian Shield and the subsiding DanishPolish Trough.

The offshore area around Bornholm has previously been investigated by Andersen et al (1975), who gave a general outline of the major structural elements mainly based on interpretation of gravity data. Seismic investigation of the Hanö Bay Basin and the Christiansø Horst north of Bornholm has been published in several papers by Kumpas (1978, 1979,1980 \& 1982). A more detailed description of the offshore area southwest of the Christiansø Horst has, however, not been published previously. The present paper is an attempt to fullfill part of that need by giving an interpretation of multifold reflection seismic data. Pertinent data on the seismic database is given in the appendix. The sections are unmigrated, generally displayed down to $3 \mathrm{sec}$, but some sections from the Rønne Graben area displayed down to $4 \mathrm{sec}$. The lack of migration renders the smaller detailes of the structures unreliable, but has enabled easy fault tracing. The data were shot offshore 
around Bornholm between 54 30' and 55 30' north and 1400 ' and 1600 ' east, of which some are shown on fig. 1 . The survey was carried out by Geophysical Service International on contract for the Danish Underground Consortium in the years 1975 and 1976. The correlation from one fault block to another is difficult due to intense faulting throughout the area. There is furthermore only one well tie available, situated on a fault block at the NW part of the Christians $\emptyset$ High separated from the rest of the area by large faults (well: 104/14-2 on fig. 1). This isolated condensed sequence has therefore given little support in the form of direct well tie. The interpretation of reflectors as lithostratigraphic horizons is therefore mainly based on comparison with the geology and tectonic development onshore Scania, Bornholm and offshore in the Hanö Bay Basin and the waters north of Poland. Reviews on the geology of Scania are given by Norling and Skoglund (1977) and Bergström et al (1982). Welldata from Scania is given by Bjelm et al (1977). Reviews on the geology of Bornholm are given in Gravesen et al (1982), Gry (1969) and Gravesen and Bjerreskov (1982). Maps and profiles from the Polish offshore area are given in Dadlez (1974) and Pozaryski et al (1979). Other papers on the northern polish geology are Pozaryski and Brochwitz-Lewinski (1978) and Pozaryski et al (1982). The interpretation is to a minor extent supported by comparison of stacking velocities with velocities obtained by refraction- seismic shooting onshore. The interpretation of the basement level has also been supported by a semi quantitative magnetic interpretation.

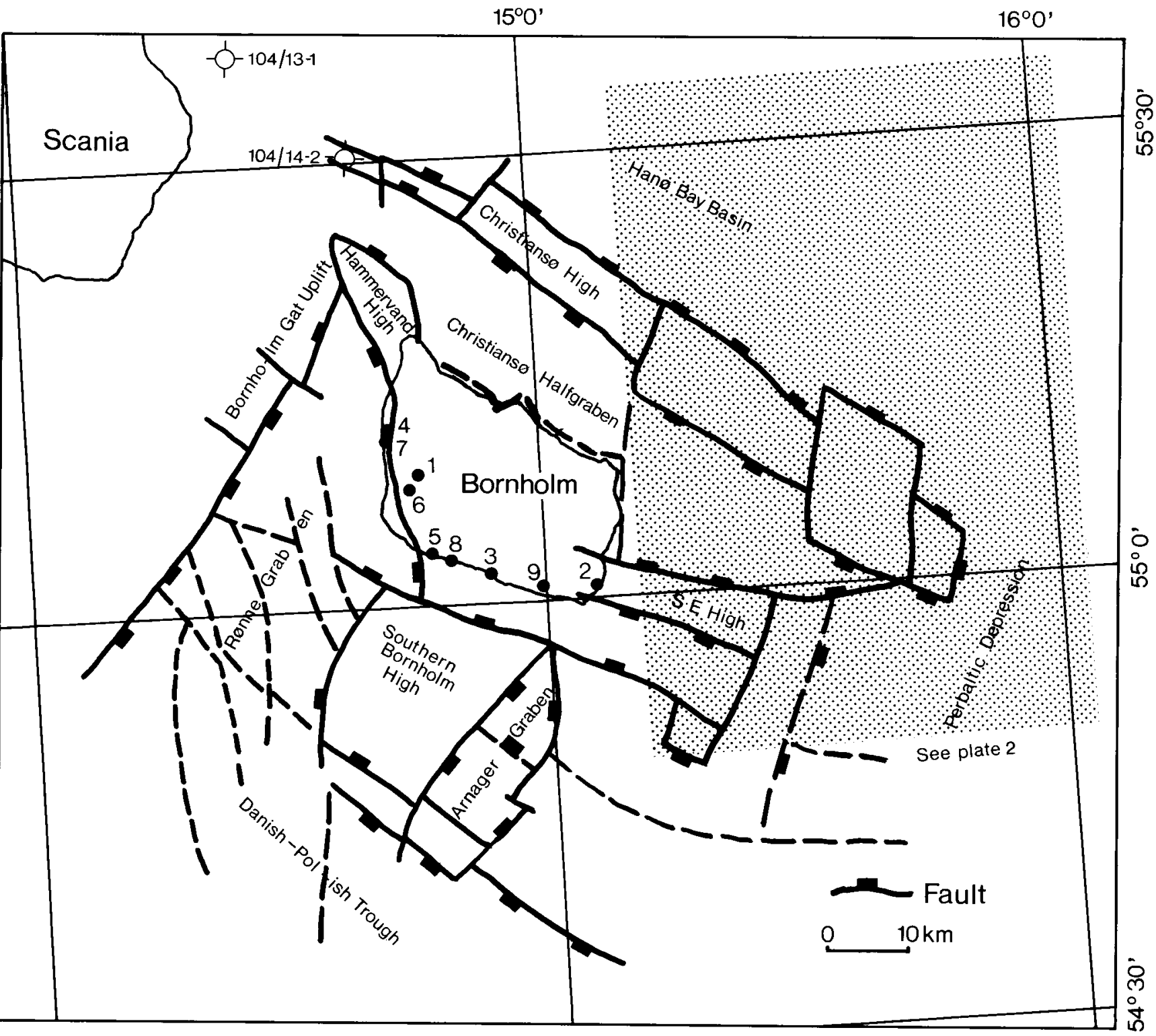

Fig. 1: This map illustrates major structural elements of the studied area. The area shaded east of Bornholm shows the location of the magnetic map, which is interpreted in this study. The location of two swedish wells (tab. 3) and the refraction seismic shooting locations (tab. 2) are also shown. The locations are: 1: Bjørnegaard, 2: Dueodde, 3: Lauegaard, 4: Nordgaard, 5: Pilegaard, 6: Risenholm, 7: Rubinsøen, 8: Sosegaard and 9: Tornegaard. 


\section{The geology of Scania and Bornholm}

The inferred sedimentary sequence of the offshore area can most likely be compared to the wellknown sequence found onshore the Bornholm island. This is listed in table 1. The sequence on the island is however likely to be very incomplete compared to that of the surrounding offshore basins. In addition the sedimentary sequence of Scania, which is somewhat similar to that of Bornholm,- though more complete,- is also listed.

The Cambrian sedimentation on the peneplanned Cambrian basement shelf was characterized by little tectonic activity and commenses with shallow water sandstones followed by black shales with intercalations of minor limestones of combined thicknesses of $200-300 \mathrm{~m}$,- greatest on Bornholm

The Ordovician sediments are also dominated by shales with minor limestones and obtain thicknesses of only 30 to $200 \mathrm{~m}$,- greatest in NW Scania (A. T. Nielsen pers. comm.). More than $1.5 \mathrm{Km}$. of strongly deformed Ordovician strata is however encountered to the south on the island of Rugen (Franke 1967). This enormous thickness (which only comprise the Upper Ordovician) is however found in a position south of the inferred Caledonian deformation front, which according to Pozaryski et al (1979) is belived to have a WNW- ESE strike just north of Rügen (compare also Pozaryski et al 1982). The deformation front is probably not present in the studied area, which is believed to be located immediately north of the front.

The Silurian consists mainly of shales with intercalations of bentonites and with some limestones and sandstones in the upper part. The series obtain a thickness of $160 \mathrm{~m}$ on Bornholm, but reaches thicknesses of 1 to $1.5 \mathrm{~km}$ in Scania Troedson (1932) in the NW - SE striking Colonus Shale Trough. The bulk of these sediments is constituted by the two uppermost units of the four units into which the Silurian is devided. The upper units are not found on Bornholm. This is the first tectonically controlled rapid sedimentation in the area, which Troedson (1932) suggested reflected a geosynclinal sedimentation as a response to the Caledonian orogeny. These Upper Silurian deposits are generally not believed to have been deposited as continuous sheets as the older sediments, but deposited in tectonically controlled troughs.

There has not been reported sediments of Devo- nian, Carboniferous or Permian ages from Scania and Bornholm, but the presence of rocks of these ages onshore Poland may suggest that Permian and possibly Carboniferous and Devonian may be present in the southern part of the study area (Dadlez 1974 and Dadlez pers. com.). It is, however, believed that erosion and continental conditions dominated these periods.

The Late Variscian (Late Carboniferous- Early Permian) rifting phase, which lead to initiation of the Danish Norwegian basin gave rise to right lateral fault movement along the Fennoscandian Border Zone according the Ziegler (1981) and Pozaryski et al (1982). This stress system was responsible for the generation of wrench related pull-apart structures such as north-south striking normal faults, as seen in the case of the Oslo- Bamble- Horn Trough according to Ziegler (1981). The stress system responsible, was dominated by regional crustal extension, which persisted from Early Carboniferous to Early Tertiary (Ziegler 1981). This fault activity may also have initiated the Höllviken Basin (see Bjelm et al 1977) of SW Scania prior to the Early Triassic sedimentation. The Late Carboniferous - Early Permian Variscian disturbances are also reflected in Scania by the intrusion af dykeswarms, generally with a WNW to a NW strike. Palaeomagnetic investigations by Bylund (1974) showed that the intrusive activity mainly took place in two episodes corresponding to somewhat different rocktypes. The first episode is of a Carboniferous age, and the second is of a Permian to maybe even Triassic age. Late Silurian ages has, however been suggested for some of the dykes. Tuffaceous sandstones af a Wenlockian age has also been found on Bornholm (Bjerreskov and Jørgensen 1983). Any other trace of possible extrusives is however believed to have been removed by the preMesozoic erosion (Bergström et al 1982).

In Scania the Lower and Middle Triassic sediments are restricted to the Höllviken basin (Bjelm et al 1977), and the southwestern part of the Skurup High beneath thick Upper Mesozoic sediments. The sediments are composed of sandstones, shales and minor limestones and dolomites.

The Upper Triassic is represented by the Kågerød Formation in Scania. The Risebæk Member of the Kågerød formation is found on Bornholm and is believed to represent the maximum extent of the 


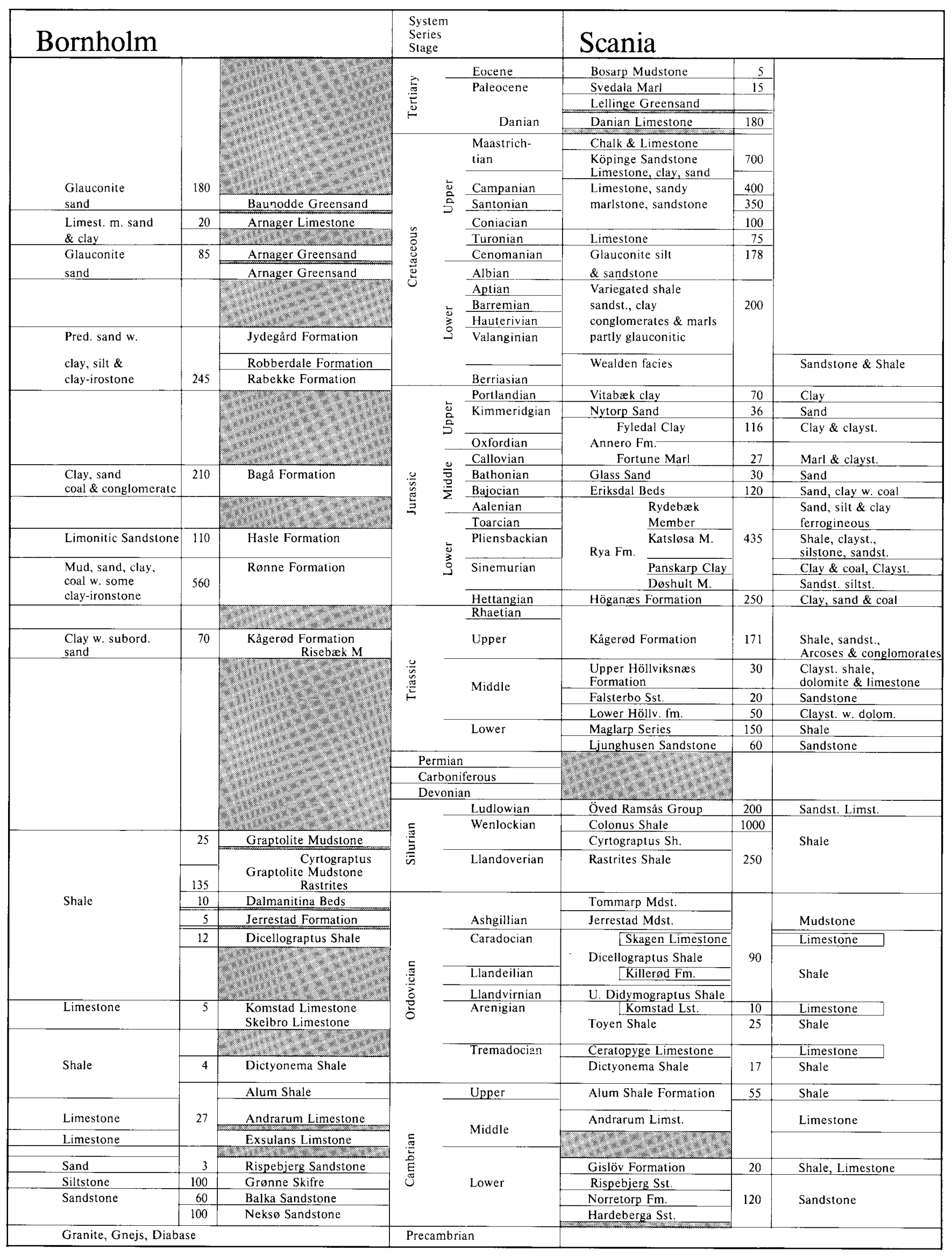

Tab. 1: Major lithological units in Scania and on Bornholm and estimated maximum thickness (metres) are listed together with the main lithological composition (Compiled after Bergström et al 1982, Gravesen and Bjerreskov 1982, Gravesen 1982, Norling and Skoglund 1977 a. o.). 
Triassic depositional basin. The continental deposits comprising arcoses, conglomerates and clays are believed to have reached as far NE as to a line connecting Kullen and Simrishamn in Scania. The coarse clastic sediments indicate source areas of considerable relief, which were produced by the Variscan disturbances. The whole of the Triassic sequence amounts to about $480 \mathrm{~m}$ in Scania.

Further tectonic activity is indicated by minor discordancies at the base of the Rhaetian in Scania (Troedson 1932), and on Bornholm by the fact that the Lower Jurassic is resting on both Keuper and Palaeozoic (Gry 1969). These movements mark the beginning of the Cimmerian phases, during which the characteristic horst structures of Scania were initiated and developed (Bergström et al 1982). Movement along the bounding faults of these structures has been intermittently active during the Mesozoic to Cenozoic eras. Movement patterns have however changed through time.

The tectonic movements were fairly quiet,- characterized by a regional westward downwarping towards the Danish Polish Trough during the Rhaetian, but during the Liassic increasing tectonic activity is seen as renewed delivery of coarse- clastic sediments in Scania (Bergström et al 1982).

At the beginning of the Middle Jurassic renewed tectonic activity (the Mid Cimmerian Phase) is indicated by the Pre-Bajocian Aalenian- Toarcian hiatus and the Middle Jurassic basal conglomerate (Gry 1969) on Bornholm. This is thought to reflect uplift and erosion resulting in a tectonically controlled regression. The Mid Cimmerian tectonic events were characterized by different movement patterns on different fault blocks in Scania,- now seen as different thicknesses and different ages of hiati. The Cimmerian phases did thus result in a great variation in lithologies on different fault blocks during the Jurassic. The lithologies are variations between sand, silt, clay, coal, marl and limestones reaching cumulated thicknesses of $1100 \mathrm{~m}$ in Scania and $900 \mathrm{~m}$ on Bornholm for the whole of the Jurassic.

The Late Cimmerian tectonism of the Late Jurassic - Early Cretaceous ages is demonstrated by occurences of Jurassic - Lower Cretaceous strata angularly truncated by Upper Cretaceous deposits in Scania (Bergström et al 1982). The Lower Cretaceous is seen to rest unconformably upon older deposits on Bornholm, representing further basin expansion facilitated by further block faulting in this period (Rolle et al 1979).

The Cretaceous tectonic regime are generally characterized by rapid subsidence. The area SW of the Romeleås High in Scania had the highest rate of subsidence during the Late Cretaceous, with up to $1600 \mathrm{~m}$ of sediments accumulated (Norling and Skoglund 1977). The Upper Cretaceous sediments are dominated by calcarous rocks in SW Scania, but with increasing proportions of sand, sandstones and conglomerates towards the NE.

The Tertiary comprises the Danian limestone and isolated occurences of Paleocene and Eocene (as the youngest pre- Quaternary sediments) in the area SW of the Romeleås High (se Norling and Skoglund 1977).

The Danish- Polish Trough became inverted in the intra Senonian Sub- Herzynian phase, but mainly the inversion took place during the Late Palaeocene Laramide Inversion (Ziegler 1981). The inversion is expressed by deformation of previously tensional basins, which obtained compressional features such as folding and uplift with subsequent erosion. The Quaternary glacial deposits are not believed to obtain sufficient thicknesses to be studied on the seismic data used in the present work. 


\section{Interpretation}

\section{Introduction}

The seismic sequences were basically subdivided without the use of well-control. The interpreted reflections were therefore picked after criterias of amplitude, structural relationships and the ability for reliable correlation from one fault block to another. The seismic sequence units presented in the following section are therefore not the smallest mapable units, but major units which by comparison with evidence from land areas may reflect the major tectonic development of the area. The difficulties encountered in the interpretation of an area as structurally complex as this inhibit reliable detailed seismic stratigraphic analysis. Only four levels of different age have thus been chosen to describe the offshore structures. The following section presents the supporting refraction and magnetic data followed by a description of the selected units, their bounding reflectors and their estimated ages. The units, reflectors and interpreted ages are listed in tabel 4.

Four reflection time depth maps and one time isopach map representing different levels in the sedimentary series were interpreted on this basis. Depth and thicknesses are given in two way reflection time due to the great scatter of the RMS interval velocities, which indicate that depth conversion is hazardous.

\section{Refraction and magnetic data}

Refraction-seismic velocities are given by Sharma (1974) and Vejbæk (1983) and listed in table 2. The velocites obtained by Sharma (1974) were derived from direct arrivals of shots on outcrops using a $100 \mathrm{~m}$ cable, where as the velocities given by Vejbæk (1983) were obtained by shooting with a $500 \mathrm{~m}$ geophonecable, using also second arrivals. The method of calculation of the results given by Vejbæk (1983) is based on the assumption that the velocity layers can be approximated either by single velocity layers or by layers with a linear increase of velocity with depth (described in Vejbæk 1983). This method required shooting as close to the strike of the sedimentary layers as possible. The formation names and informal rock unit names used in the tables are given in Gravesen \& Bjerreskov (1982) and Gravesen et al
(1982). The results indicate that good reflectors may be found at the top of the basement, the top of the Palaeozoic and within the Jurassic and Cretaceous sediments. Apart from the velocities obtained onshore, velocity data from the swedish wells 104/13-1 and 104/14-2 were also used (tab. 3 and fig. 1). These data show that good reflection coefficients are to be expected at the following horizons: the top of the Palaeozoic, the top of the Lower Middle Jurassic, in the Middle Barremian, in the Coniacian sediments and at the top of the Middle Santonian. The refraction velocities given in table 2 are probably too low due to little overburden at the refracting horizons as compared to the velocity at the depths reached by the reflection seismic shooting. The small scatter of the refraction- seismic velocities for the different rocktypes indicates that they may be used to obtain consistent, but somewhat underestimated depth and thickness estimations.

The interpretation of the basement level has been supported by magnetic data in the eastern part of the investigated area. The magnetic data was an aeromagnetic map in 1:200.000 scale, covering $58 * 64$ squarekilometer (se fig. 1 for location). It is contoured with a 5 isogamma interval, and is part of a larger map made by Companie Generale de Geophysique on contract for the Danish Underground Consortium (1974). The map was interpreted with semiquatitative depth estimation ('Peters method' among others) and interpreted depth values have been contoured with an interval of $0.5 \mathrm{Km}$. 


\section{Interpretation of reflection seismic data}

\section{Basement (plate 1 \& 2)}

This unit is only limited upwards by the basement reflector and is thus interpreted to represent the acoustic basement. The unit is generally reflection free or with diffraction hyperbolas (see f. ex. the Hammervand High on fig. 2). The unit is thought to represent Proterozoic igneous and highgrade metamorphic rocks. The RMS velocities of the unit show great scatter, but tend to gather around $4.8-5.0 \mathrm{Km} /$ sec.

The upwards limiting basement reflector, which is simply defined as the lowermost mapable reflector, show great variation in amplitude, which is partly a function of the overlying sediments, but is probably also to a large extent due to seismic processing difficulties. The reflection amplitude is very strong in most of the area, but east of Bornholm and in the eastern part of the Hanö Bay Basin it seems to lose strength and become extremely weak. This is partly

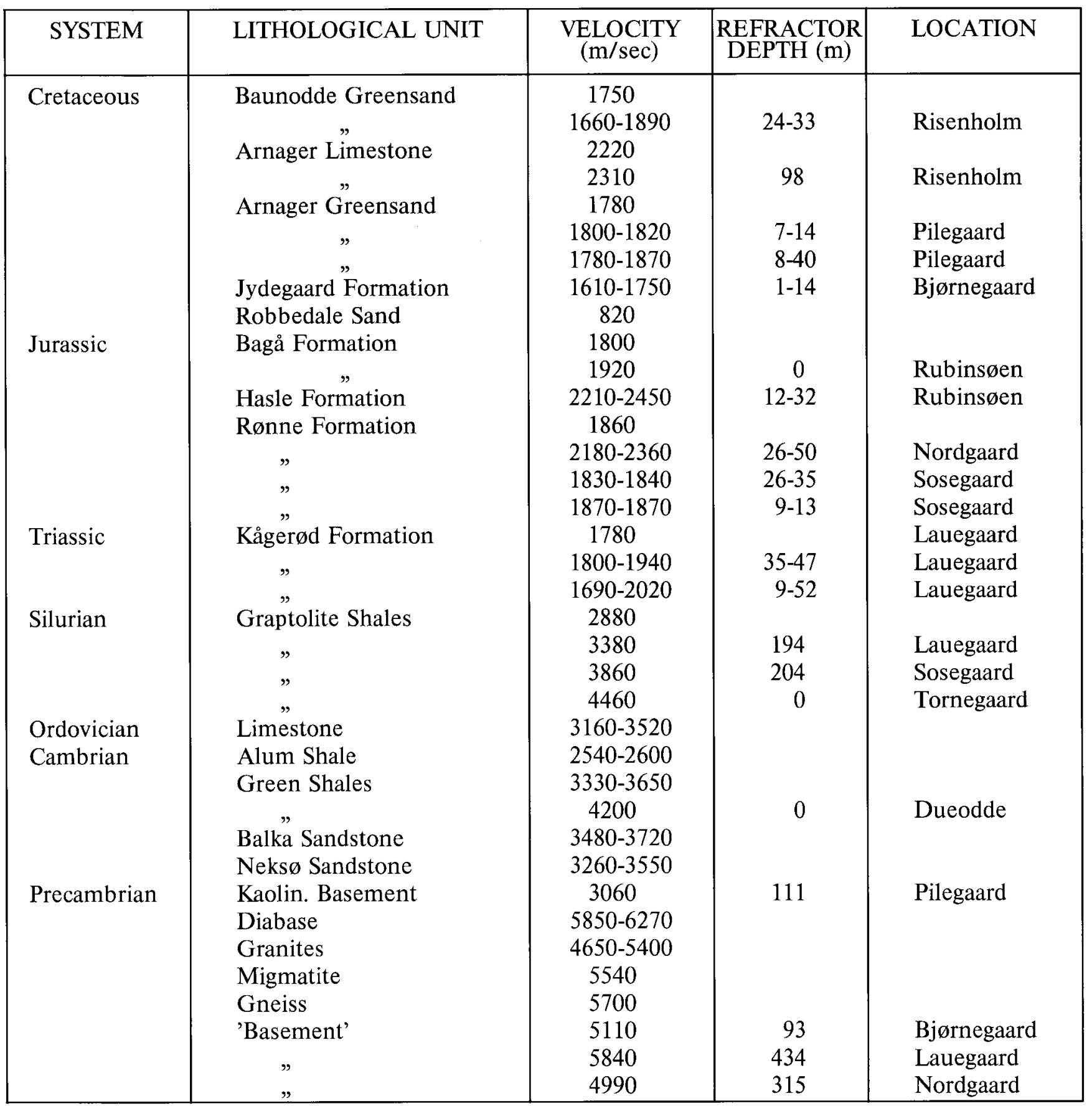

Tab. 2: Velocities obtained by refraction seismic shooting on outcrops a $100 \mathrm{~m}$ cable are listed without depth and location reference (Sharma, 1978). Velocities obtained by refraction seismic shooting using a $500 \mathrm{~m}$ cable are also listed together with the calculated refractor depth and the location of the shot (after Vejbcek 1983). The localitions are shown on fig. 1. 


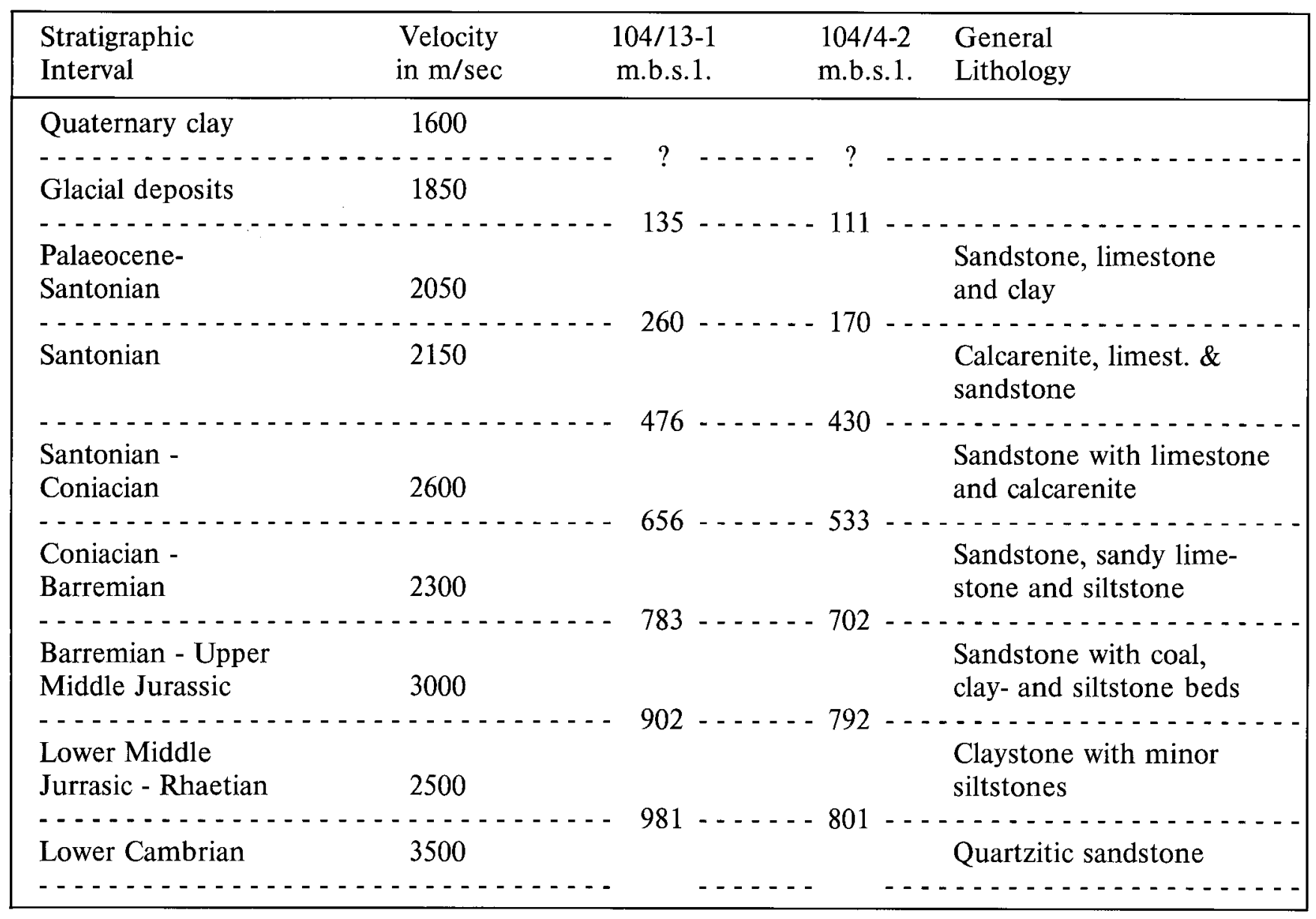

Tab. 3: The velocity interval division of the two swedish wells 104/13-1 and 104/14-2 with the interface depth and geologic age of the intervals are given. The bulk lithological composition of the individual intervals is listed to the right. (Modified after Kumpas 1977).

\begin{tabular}{|c|l|l|}
\hline REFLECTORNAME & DEFINED AS & INTERPRETED AGE \\
\hline C & $\begin{array}{l}\text { Base unit 4 } \\
\text { Top of unit 2 } \\
\text { Base unit 2 (\& } \\
\text { A }\end{array}$ & $\begin{array}{l}\text { Base Unper Cretaceous (+ Barremian) } \\
\text { Intra Triassic or Intra Lower Jurassic }\end{array}$ \\
Basement & $\begin{array}{l}\text { The sub Mesozoic peneplane } \\
\text { Top of the Precambrian basement }\end{array}$ \\
\hline
\end{tabular}

\begin{tabular}{|l|l|l|}
\hline UNIT & BOUNDING REFLECTORS & INTERPRETED AGE \\
\hline Unit 4 & C at the base & Upper Cretaceous - Danian \\
Unit 3 & C at the top and B or & Upper Triassic or Lower \\
& A at the base & Jurassic - Lower Cretaceous \\
Unit 2 & B at the top, A at the Base & Triassic (+ Lower Jurassic ?) \\
Unit 1 & Basement reflector at base, & Lower Palaeozoic (+ locally \\
& A, B or C at the top & Upper Palaeozoic ?) \\
\hline
\end{tabular}

Tab. 4: The reflectors and the units defined by these reflectors are here listed together with the assumed ages. 
due to relatively high velocities of the overlying sediments, but also due to unsuccesfull stacking. It has thus been necessary to support the seismic interpretation with a magnetic interpretation (plate 2). The magnetic depth map is in general in agreement with the seismic basement map, but 2 isolated shallow anomalies in the southern part of the magnetic map may indicate igneous intrusions (ie. basic dykes).

The resulting seismic basement map (plate 1) clearly depicts the slope and trend of the individual sedimentary basins, except south of the Southern Bornholm High. No good reflector is found in this area, but magnetic data indicate a deep basement. The area thus is shown with a time depth of more than $3 \mathrm{sec}$, which is the lower range of display for the sections of that area. This is in agreement with the observations in the Rønne graben, where the basement is seen to become deeper to the south,- and in the Peribaltic Syneclise where the basement grows deeper to the east and to the south. The increase in the structural complexity of the area towards the SW is clearly demonstrated by the increasing amount of mapped faults.

\section{UNIT 1 (plate 3)}

This unit is found in the southern end of the Rønne Graben, in the Arnager Graben, east of Bornholm, and in the eastern half of the Hanö Bay Basin. The two latter areas may mark the western edge of the Peribaltic Syneclise which deepens to the east (see fig. 3 and 4). The unit is bounded downwards by the basement reflection, and upwards by the $\mathrm{A}$ or $\mathrm{C}$ reflectors, depending on the area. The unit is upwards bounded by the A reflector in the Rønne Graben, Arnager Graben and on the eastern half of the Southern Bornholm High. Anywhere outside these areas the unit is bounded upwards by the $\mathrm{C}$ reflector, which has a very high amplitude. The unit is characterized by being homegeneous or concealed internally by multiples. No internal primary reflection has been positively identified anywhere in this interval. The thicknessvariations illustrated by the isopachous map (plate 3 ) show the rapid increase to the east and to the south (see fig. 3 and fig. 5). The southern increase in thickness is particularly evident in the southern Rønne Graben where thicknesses of more than $2 \mathrm{sec}$ are obtained (Compare also fig. 2). This correspond to thicknesses of around $4 \mathrm{Km}$ given a velocity of $4 \mathrm{Km} / \mathrm{sec}$ as an estimated avarage velocity of deeper buried Palaeozoic sediments (compare table 2). Similar thicknesses are believed to be present just south of the Southern Bornholm High indicated by magnetic data, though the lower limit has not been encountered in any section in this area due to the display cut off. The unit is believed to have been deposited before the initiation of the Rønne
Graben, because the basin axis is perpendicular to the axis of the Rønne Graben. The present great thicknesses found in the southern Rønne Graben may however be a result of preservation against erosion following the initiation of the Rønne Graben.

The interpreted extent of the unit in the Rønne Graben is in opposition to other interpretations. Other interpretations show that unit 1 of the southern part of the Rønne Graben is equal to unit 2 of the northern part of the Rønne Graben (fig. 2). The interpretation in this paper is presented for the purpose of discussion and not because it is felt that the interpretation of this paper is more correct.

Comparison of the basement map (plate 1) and the time isopach map (plate 3) show that thicknesses change abruptly across most of the faults marked on the basement map. This is belived to indicate that tectonic activity have taken place during and (probably predominantly) after the deposition of the unit 1. These older fault zones have in most cases also been reactivated by later stress systems, as most of the faults also displace stratigraphically higher levels.

The unit is interpreted to represent Palaeozoic sediments, mainly based on comparison with maps and papers published by Polish writers (Dadlez 1974, Pozaryski et al 1979 and others). Interpretation of the Hanö Bay Basin by Kumpas (1979) also support the interpretation. Maps published by Kumpas (1979 pp. 72) show that only few minor pockets of Palaeozoic sediments are found in the Hanö Bay Basin west of the eastern edge of Palaeozoic sediments shown on the time isopach map (plate 3). Local maximum thicknesses of $100 \mathrm{msec}$ corresponding to $200 \mathrm{~m}$ may be found (using a velocity of $4 \mathrm{~km}$ / sec). However these pockets are not seen in the sparse data available in this survey in the Hanö Bay Basin. The erosional limit of Palaeozoic sediments indicated on the isopach map (plate 3 ) is therefore expressing the limit of thick Palaeozoic (more than about $50 \mathrm{msec}$ ). The correlation to the Arnager Graben and Southern Bornholm High is supported by the known relations of the Palaeozoic sequence onshore Bornholm, which show the same general eastward increase in preserved thickness (cf. Geological Survey of Denmark 1980). The correlation to the Rønne Graben area is based on more indirect considerations. Comparison is made to the sections published by Dadlez (1974), which show rapidly increasing thicknesses of Palaeozoic sediments to the south towards the Caledonian deformation front. The thick sequences in the Rønne Graben and south of the Southern Bornholm High may also be regarded as a southwestward continuation of the Peribaltic Syneclise. The fact that the Palaeozoic sediments in Scania obtain thicknesses of more than $1.5 \mathrm{~km}$ and is of a seismically rather uniform lithology also 
seems to support a Lower Palaeozoic age for the lower unit. The enormous thickness of the unit is however very much greater than the thickest Palaeozoic sequence found in Scania, though the thickest parts of the sequence may be more complete and even include some Upper Palaeozoic sediments.

Fig. 2: Line B76-021 Section through the longaxis of the Rønne Graben. For location see fig. 15. SSW

\section{UNIT 2 (Plate 4)}

This unit is only found in the Rønne graben. Rocks of similar age as this unit may also be present south of the Southern Bornholm High and in the Arnager Graben, but a major N-S striking reverse fault with a displacement of up to $1 \mathrm{sec}$ (see fig. 6) prevents reliable correlation of the upper bounding $\mathrm{B}$ reflector. The unit is bounded downwards by the A reflec-
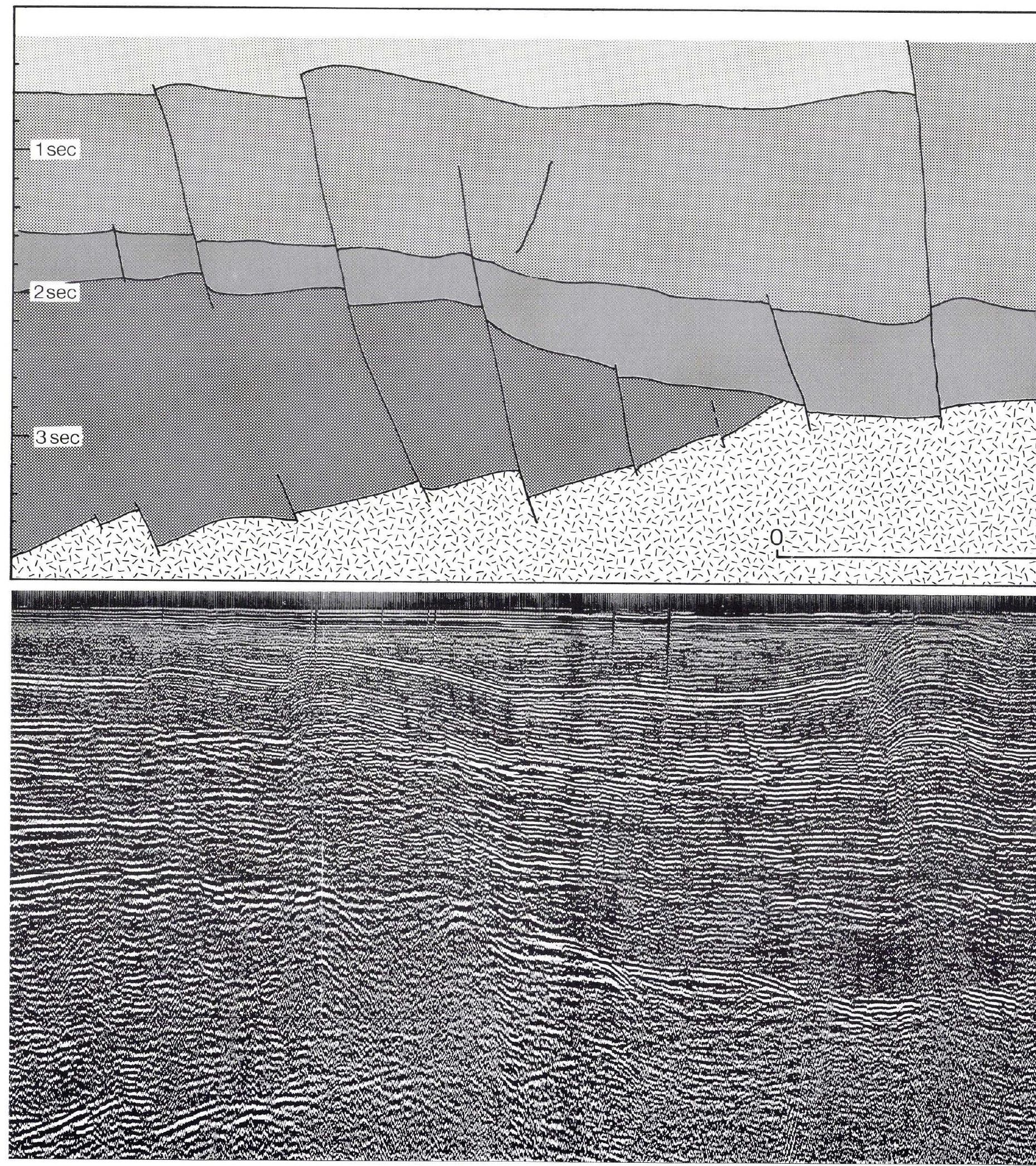
seems to have had an east west trend as indicated by the isopach map of this unit (see fig. 8). This strike is constituted by smaller local wedges, which thicken to the north in some sections (fig. 9). This indicates sedimentation on smaller fault blocks bounded by listric normal faults (concave to the south on fig. 9). Movements along these faults have however been reversed as seen on fig. 9. The lower bounding sur-

WNW
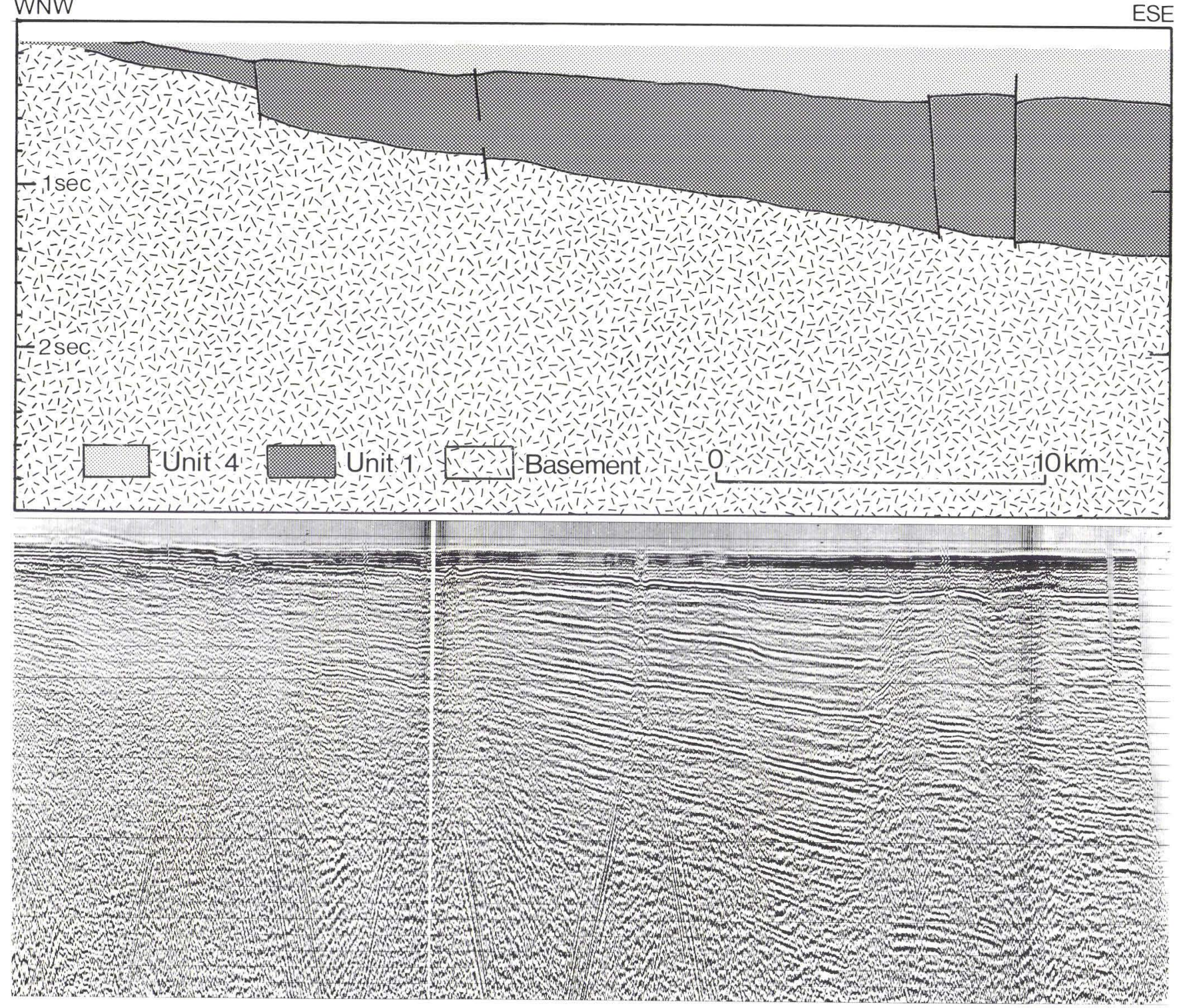

Fig. 3: Line B76-012 from the area east of Bornholm demonstrates the eastwards increase in thickness of Palaeozoic, sediments towards the Peribaltic Depression. Interpretation is impeded by abundant multiples. Note the strong appearance of the $C$ reflector, the unusually strong appearance of the basement reflector of the eastern area. For location see fig. 15.

WNW

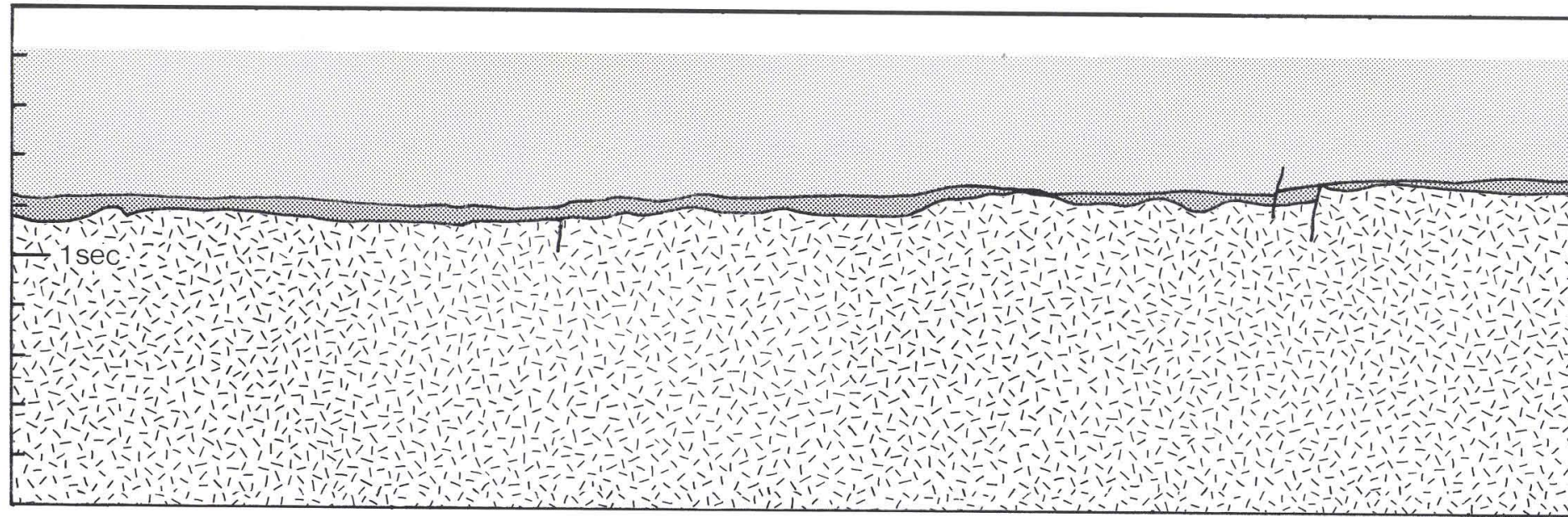




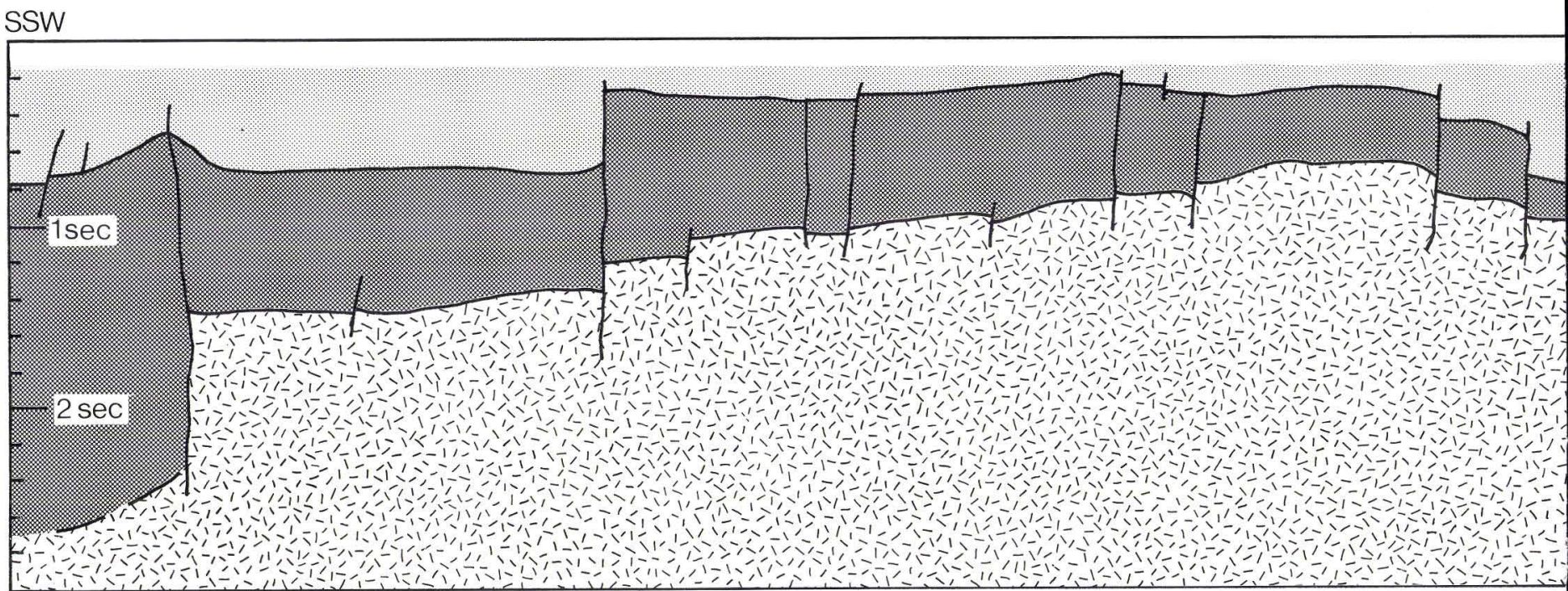

Fig. 5: This NNE - SSW striking section (B-75-005) demonstrates the sequence east of Bornholm. The Hanö Bay Basin is seen to the extreme right. The Christiansø High is seen in the Middle. Note the southward increasing thickness of Palaeozoic sediments. For location see fig. 15.

through the Rønne Graben, and do thus vary in thickness from approximately $0.5 \mathrm{sec}$ in the southern part to almost $2.5 \mathrm{sec}$ in the northern part of the Gra- ben. This increase in thickness is accompanied by divergence of the internal reflections, indicating that the thickness variation is due to synsedimentary differential subsidence in the Rønne Graben (fig. 2). The areas where the unit obtain greatest thicknesses are also the areas, where the upper bounding $\mathrm{C}$ reflector is absent due to uplift and erosion. It is therefore obvious, that the maximum thicknesses may have been even greater initially, and that the relief in

WNW
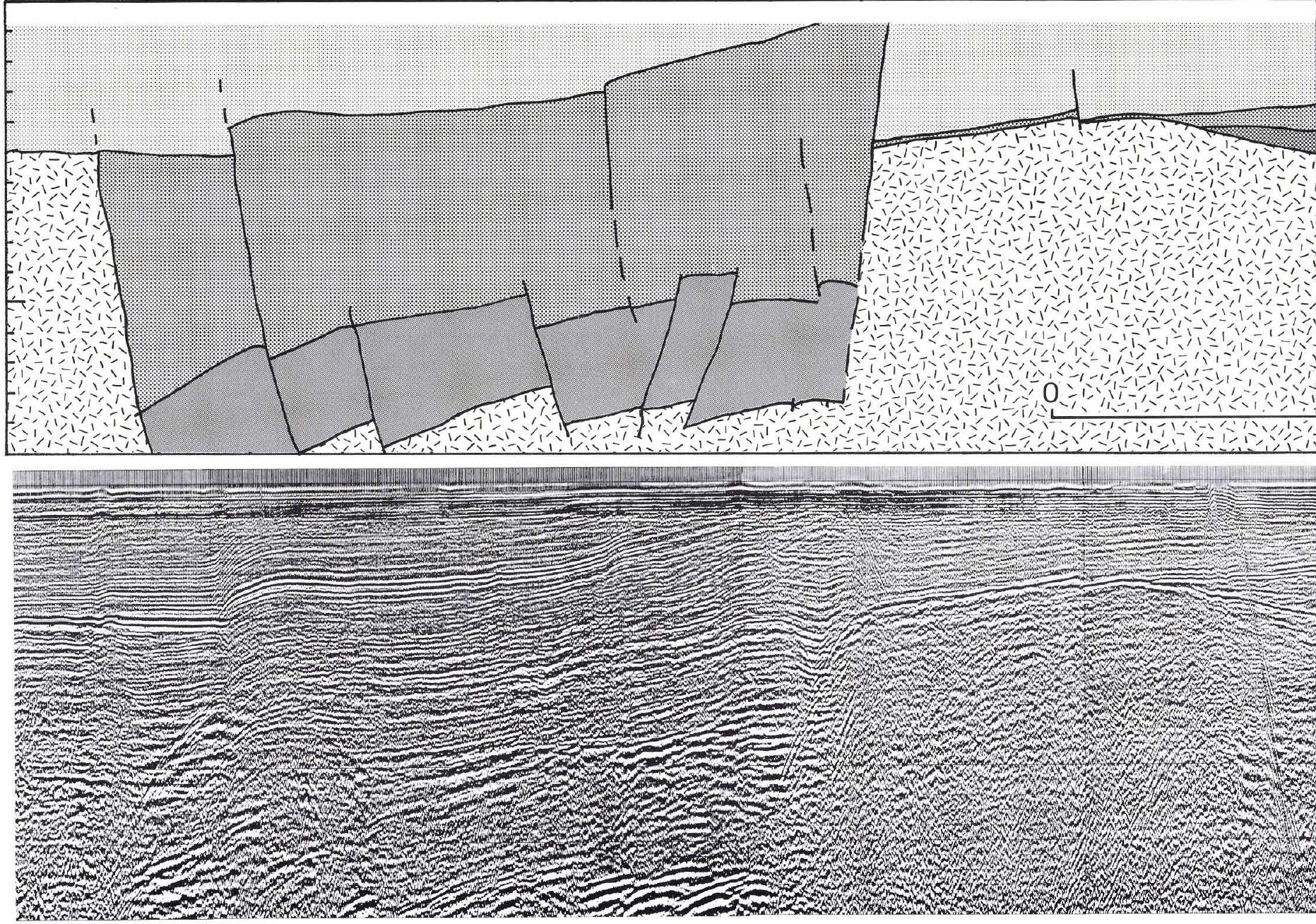
unit 3. The unit has a similar appearance in the Arnager Graben, with many internal reflections of intermediate amplitude and some continuity. The lower bounding A reflector which represents the interface between unit 1 and 3 in the Arnager Graben, is rather strong.

The unit is generally seen to have an uniform thickness along N-S striking sections in the Arnager Graben, except when the unit is eroded in the northern part (fig. 10). The apparent eastward dip of the basin floor in the Arnager Graben is compensated by the wedge shape of unit 1 (fig. 6). The rotational movement of the basin floor in this graben was therefore accomplished during the deposition of unit 1 or more likely after, accompanied by erosion.

The age range of the unit presents some of the same problems as those of unit 2, with regard to age of the lower boundary. A Jurassic age for the bulk of
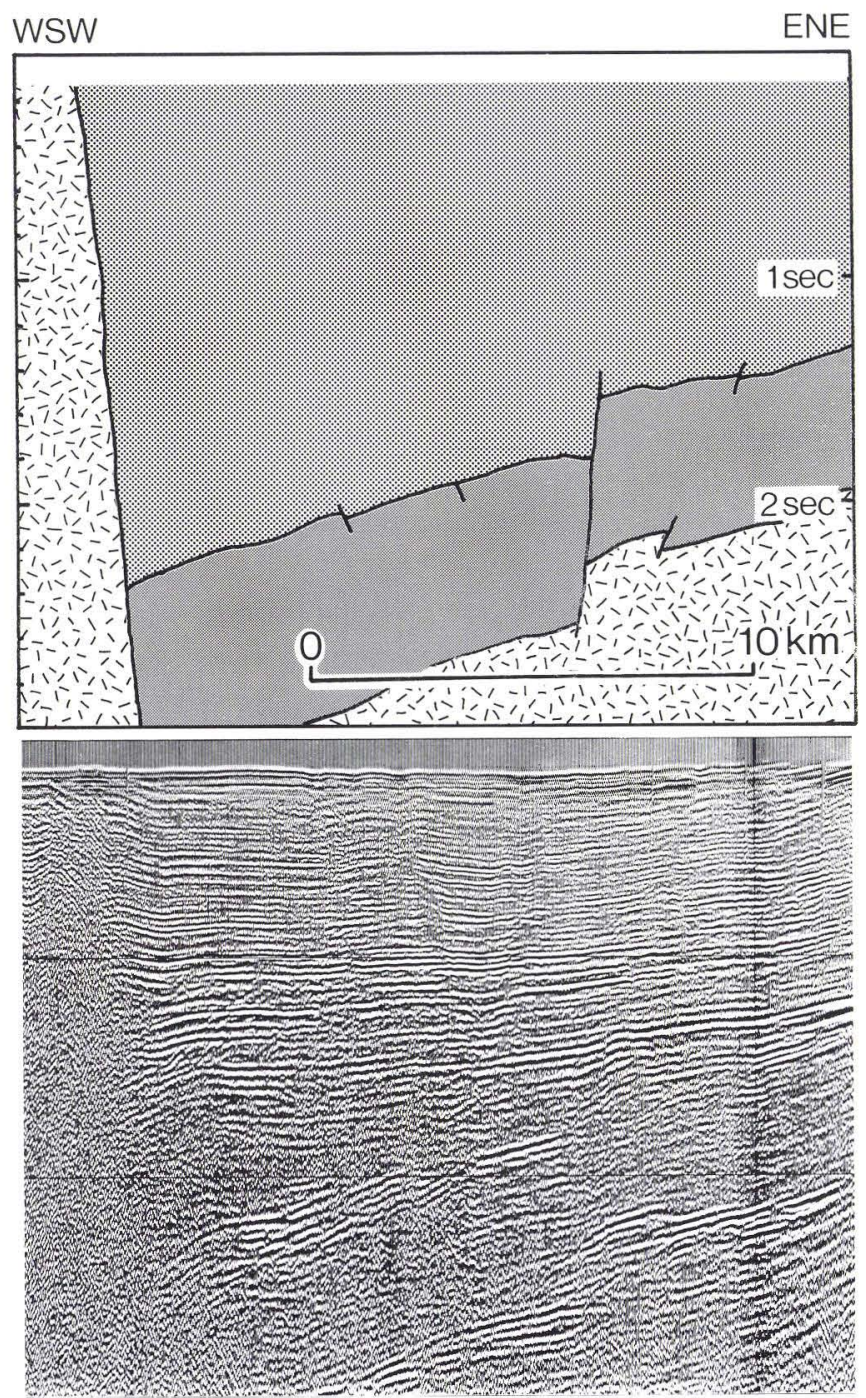

Fig. 7: The relation between the 2. and the 3. unit is well demonstrated with line B76-034. The B reflector is not parellel to the internal reflections of the 3. unit. The disrupted internal reflection configuration of the 3. unit is typical. It is probably due to ubiquitous minor faulting. Note minor internal discordancies of the 3. unit. Note the fault limited to the 2. unit only. For location see fig. 15.

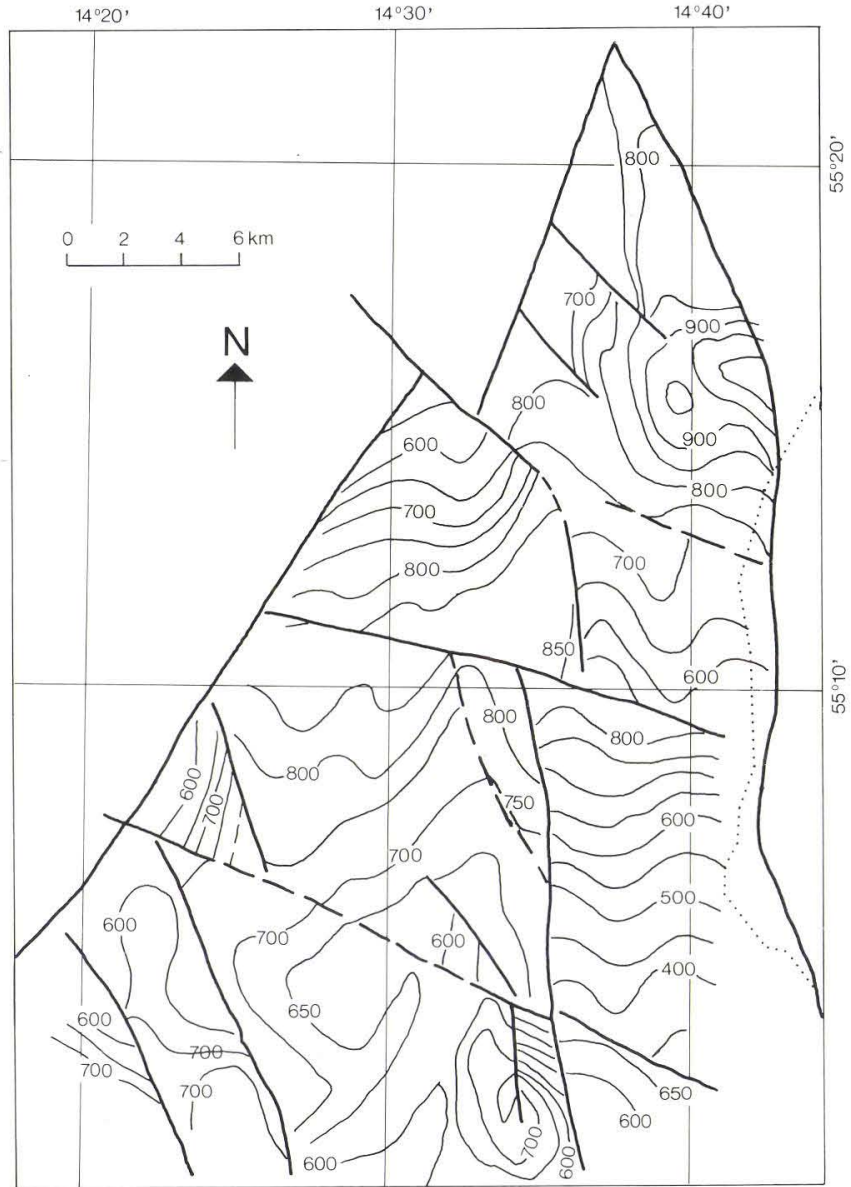

Fig. 8: The thickness in msec of the 2. unit of the northern part of the Rønne Graben as a time isopach map. The complexity of the southern end of the Rønne Graben prevents detailed contouring. Faults are marked by heavy lines. Thickness variations are clearly fault-controlled.

the unit seems likely, because the great amount of internal reflections indicate a great variation in the lithology of the unit, which is also known to be the case for the Jurassic sequence found in Scania and on Bornholm. Some of the unit as defined in this context is exposed on the west coast of Bornholm. The exposed Mesozoic sequence comprises $750 \mathrm{~m}$ of Lower to Middle Jurassic sands, clays and coal. The interpreted sequence on the Southern Bornholm High and in the Arnager Graben seems to be supported by the known relations from the southern part of the island of Bornholm. This is also supported by the velocity information in the refraction seismic data from the south coast (compare Lauegaard location table 2), which show a relatively thick Mesozoic sequence on top of a Palaeozoic sequence.

The unit is also believed to include most of the Lower Cretaceous as discussed for unit 4 (see below).

\section{UNIT 4 (Plate 6)}

This unit is limited downwards by the fairly strong $\mathrm{C}$ reflector, and upwards by the seafloor. The unit show 
several fairly continuous internal reflections of moderate to weak amplitude in most sections. Some of the reflections show faint low angle discordancies at one or two levels (fig. 11 and 12) indicating moderate synsedimentary tectonism. The internal reflections are, however, generally parallel to the lower bounding $\mathrm{C}$ reflector, being straight or gently flexured at, or close to faults. The unit has the form of a wedge in the Hanö Bay Basin, with the deepest parts close to the Christiansø High and gently tapering towards the northeast. The unit is also tapering in an easterly direction east of Bornholm (fig. 4). It is characteristic that the unit is not cut by normal faults in, or at the boundaries of the Rønne Graben and the Arnager Graben, but only reverse faults or fault flexures (see fig. 6 and plate 6 ). Some of the approximately NW-SE striking faults outside the two grabens show reverse components at the $\mathrm{C}$ reflector level. The actual nature of many of these faults has however not been acertained, due to a very steep dip of the fault planes which prevents determination of fault nature in the seismic sections of this study. It is remarkable that the only reverse faults of an approximate N-S strike are found in or at the boundaries of the two grabens. The lower bounding $\mathrm{C}$ reflector is even totally missing due to uplift and erosion in the northern end of the Rønne Graben and parts of the Arnager Graben. The unit is also thin or absent on the Hammervand High, the Dueodde High, and on Christiansø High (except at the NW end). The unit is never the less the most widespread of all units representing sedimentary rocks, the lower bounding $\mathrm{C}$ reflector being close to the top of the basement in the western part of the Hanö Bay Basin, in major parts of the Christiansø Half-graben, west of the Rønne Graben and on the western part of the Southern Bornholm High. It is resting on top of unit 1 in the western part of the Hanö Bay Basin, east of Bornholm and east of the Arnager Graben. It is resting on top of unit 3 in the Rønne Graben and in the Arnager Graben.

The age range of the unit is believed to span the whole of the Late Cretaceous, the Danian and some Palaeocene topped by thin Quarternary glacial drift. The lower age is mainly based on the velocity information from the two swedish wells (table 3 ), which show a marked increase in velocity in the Barremian, which may correspond to the easily correlated C reflector. It can be argued, whether the Lower Cretaceous sequence should be enclosed in the upper unit. It is however seen that the termination of graben tectonics and the development of interior sag basins (se also Harding 1982) in the Danish Consession area generally commences with the Upper Cretaceous, whereas the Lower Cretaceous belongs to the graben fill sediments as for instance seen in the Central Graben area (cf. Andersen et al 1982). This may apply to this area, where unit 4 show no normal faulting in connection with the Rønne Graben and the Arnager Graben. The observations in the swedish wells 104/13-1 and 104/14-2 seems to support this idea, though with the Lower Cretaceous down to the Barremian included (tab. 3.). It appears that sedimentation from the Late Barremian to the Early Coniacian is fairly continuous, or at least does not
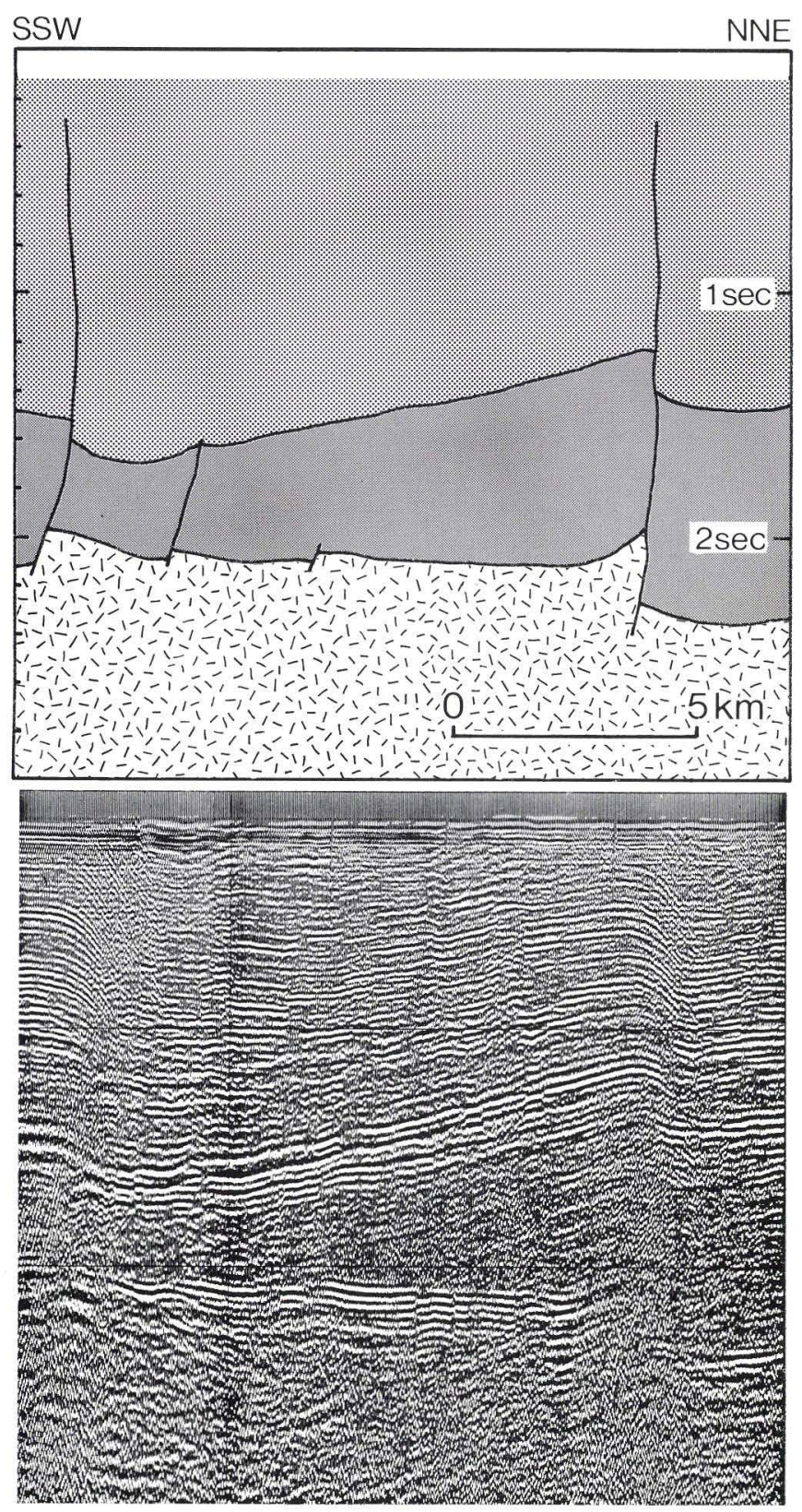

Fig. 9: This part of line B76-022 from the Rønne Graben depicts the northward diverging wedges of the 2. unit. The generation of the wedges are explained by rotational blockfaulting along listric normal faults concave to the south, during the deposition of the sediments represented by the 2 . unit. The typical discontinuous internal reflection of the 3 . unit, which on this scale show local southward divergence, show that the rotational movement of the faultblock was somewhat reversed during the deposition of the unit, and possibly simultaneously with the deformation of the 4. unit. Note the typical appearance of the $B$ and the $A$ reflections, and the typical internal reflection configuration of the 2. and 3. unit. For location see fig. 15. 
create any acoustic boundaries. The Pre-Barremian Mesozoic rocks of the Hanö Bay Basin have been successfully identified by Kumpas (1979)(see also fig. 13). These sediments have also been identified in this study as seen on fig. 4 , but only on so few lines, that the occurence of these rocks cannot be illustrated more accurately than on fig. 13 .

Unit 4 is probably most completely developed in the SW part of the investigated area, where the greatest thicknesses are found (compare plate 6). This part is believed to be directly comparable to the section found on the Skurup High of southern Scania (se Bergström et al 1982). The highlying basement bordering the Rønne Graben to the west may even belong to the same structural unit as the Skurup High. The sequence may similarly include sediments of Eocene age in parts. The unit is thought to have had a rather uniform thickness gently tapering in a northeasterly direction throughout the studied area. The primary thinning of the unit towards the $\mathrm{NE}$ is demonstrated by the decreasing stratigraphic range of Cretaceous sediments and increasing range of hiati across Scania in a northeasterly direction (Bergström et al 1982). The thinning towards the NE is however mainly a result of uplift and erosion also pointed out by Kumpas (1979), who showed that the Quarternary subcrop obtain progressively older ages towards the NE in the Hanø Bay Basin.

Fig. 10: This NNE - SSW striking section (B76-025) demonstrates the interpretation in the Arnager Graben. For location see fig. 15.

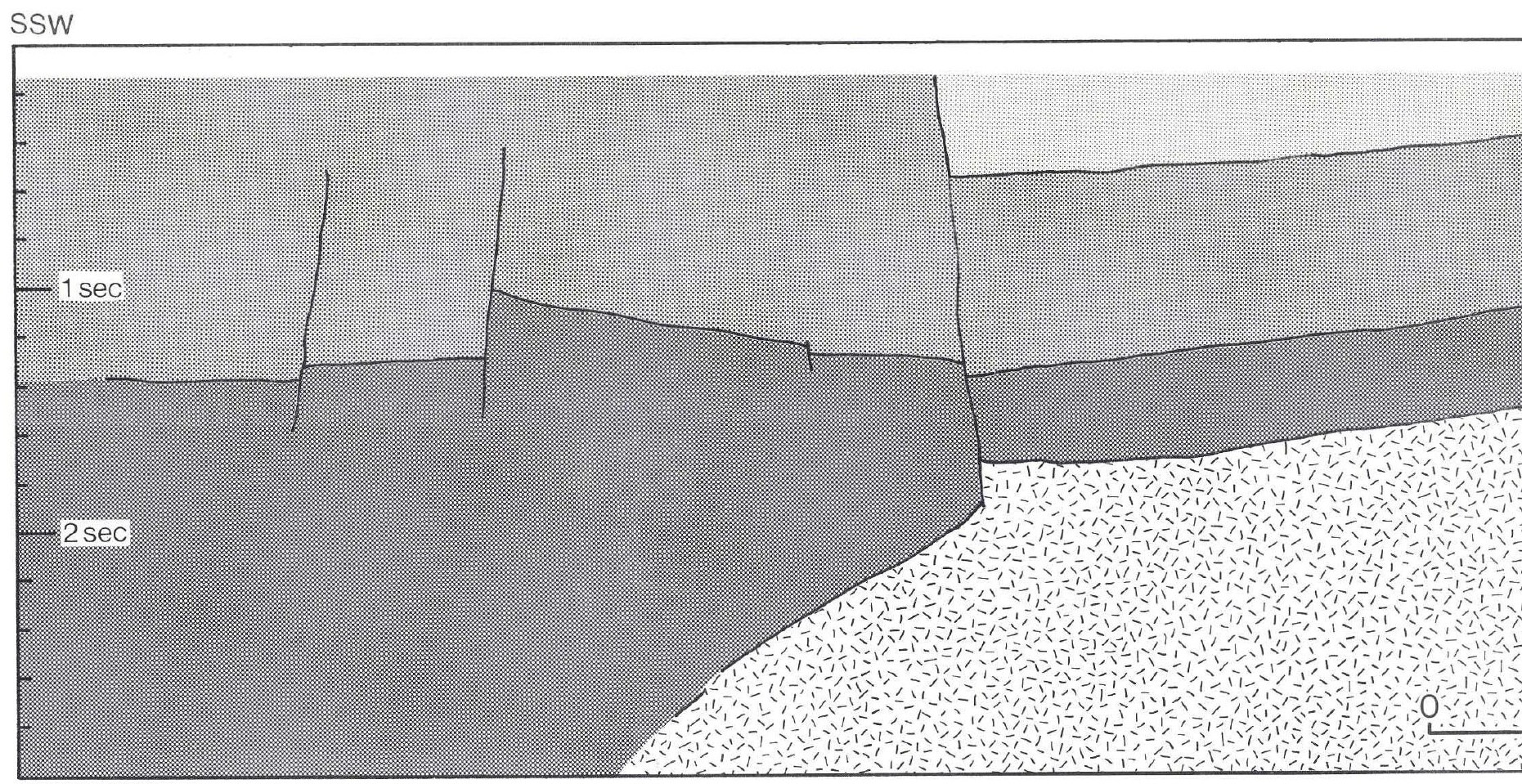


Fig. 11: This part of line B76-019 demonstrates the thickest parts of the 4. unit found close to the Bornholm Gat Uplift (to the right). The unit is resting almost directly on the Precambrian basement. Some thin older Mesozoic deposits may be found below the $C$ reflector, especially in the southern part. Minor discordancies are found f. ex. around a depth of 700 msec. For location see fig. 15 . controlled), as exposures of the boundary between Lower Palaeozoic and Mesozoic deposits indicate severe truncation at the base of the Mesozoic. This is also deduced from the discontinuous character of the northern limit of thick Palaeozoic series as seen on the island of Bornholm and in the Rønne graben

SSW
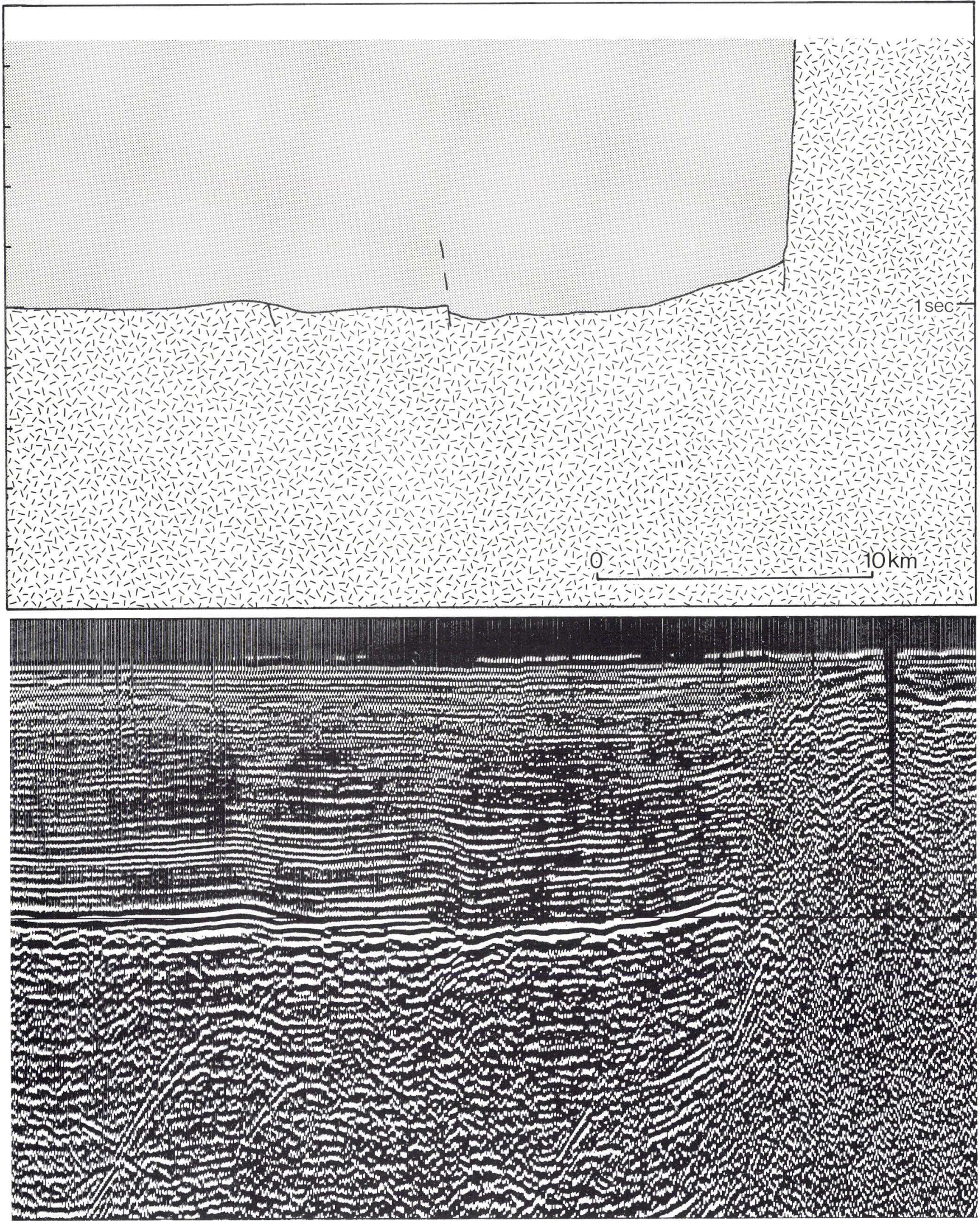
(plate 1 and plate 3 ). The limitation of the Palaeozoic series as seen on line B76-021 (fig. 2) is best explained by an angular unconformity. This view is further supported by the fact that isolated patches of Palaeozoic erosional remnants are reported from the northwestern part of the Hanö bay (Kumpas 1979) and from SE Scania lying on top of the Linderöd horst. Nevertheless the Lower Palaeozoic series has been reported to be thinning in a NE direction (Troedson 1932). The preserved immense thicknesses of the Palaeozoic series may thus reflect remnants of geosynclinal sedimentation in connection with the Caledonian orogeny (cf. Troedson 1937) The main erosive phase was conditioned by the Early Permian -
Late Carboniferous tectonic disturbances contemporaneous with the faulting in the Oslo area (Regnell $\&$ Hede 1960), and contemporaneous with the initiation of the Rønne Graben and Arnager Graben, as discussed below. Some Devonian and Carboniferous may be found in the top of unit A in the southern part of the investigated are, though the period was mainly dominated by erosion.

Fig. 12: This part of section B-75-015 from the Rønne Graben area demonstrates the typical appearance of the $C$ reflector and the 4. unit. The C reflector is quite strong both when lying on top of Precambrian basement (west of the Rønne Graben), and when lying on top of the 3. unit. Note the typical continuous internal reflections on the 4. unit. For location see fig. 15.
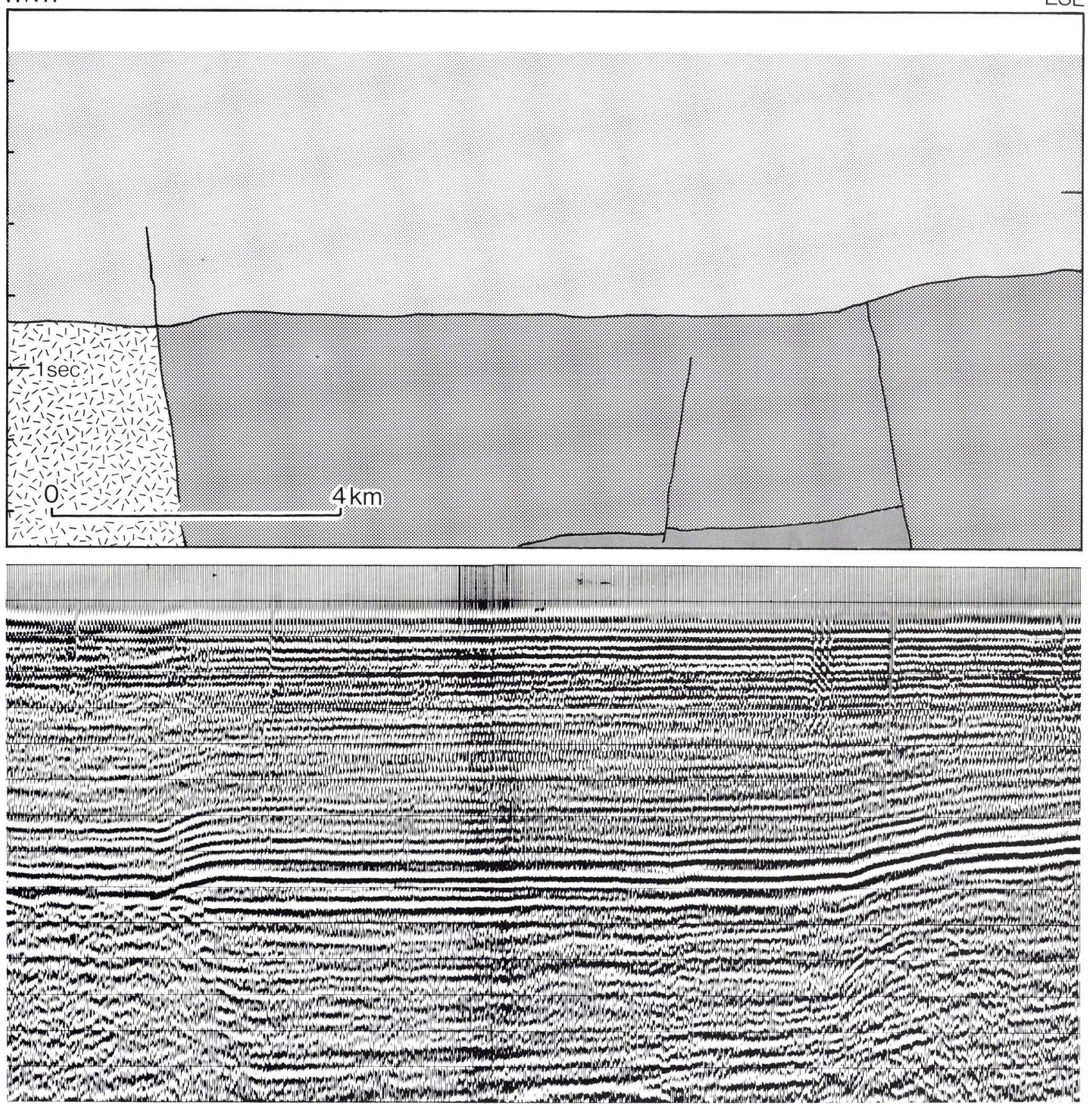


\section{Mesozoic}

The initiation of the Rønne Graben and the Arnager Graben may have been caused by the regional crustal extention that lead to the subsidence of the Danish Polish Trough and the Danish Norwegian basin in Late Carboniferous - Early Permian times (Ziegler 1981). This stress system gave rise to a right lateral wrench fault system that according to Ziegler (1981) and Pozaryski et al (1982) governed basin subsidence along the Fennoscandian Border Zone. This wrench faulting was accompanied by development of aulacogenic depositional basins of which the Oslo Graben is a wellknown example and the Rønne Graben and the Arnager Graben may be other examples. A tensional dominated wrench fault system oriented like this, is liable to develop north south striking normal faulting,- especially in a diverging / converging or en-echelon arranged system of wrench faults. It is thus possible to compare the Rønne Graben and the Arnager Graben genetically with the Oslo Graben and with the Höllviken Graben of SW Scania. The first major graben fill of the Höllviken Graben of SW Scania are the Triassic sediments (Bjelm et al 1977). An earlier primary graben fill in the Rønne Graben and the Arnager Graben of Permian sediments is, however, also possible, because sediments of these ages have been encountred in the Polish offshore area (Dadlez 1974). The A reflector of the Rønne Graben and Arnager Graben can then be interpreted as the Sub Mesozoic Peneplane. The Sub Mesozoic Peneplane is delineated by the $\mathrm{C}$ reflector outside these grabens, with small departures as seen in for instance the Hanø Bay Basin (se fig. 4). The stress system could explain the reactivation/ generation of most of the approximately N-S striking faults of which some

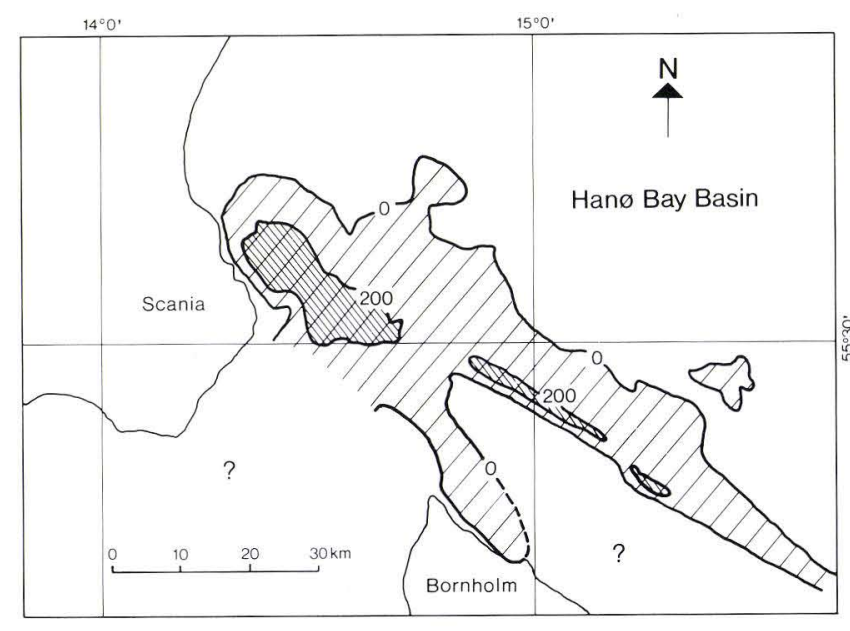

Fig. 13: The occurence of Rhaetian-Lower Barremian sediments in the Hanö Bay Basin (from Kumpas 1979) and the Christiansø Halfgraben (based on data used in this study) is here depicted by their $200 \mathrm{~m}$ and $0 \mathrm{~m}$ isopachous contours. The southern limit in the Bornholm Gat is unknown. later achieved a reverse component (see below). The initiation and subsidence of these grabens is, however not likely to be exactly syncronous, but may occur at different places at different times. This might be demonstrated by the slight rotation of the graben floors along the long- axis when comparing the Rønne Graben and the Arnager Graben: the rotational movement took place stratigraphically mainly below the A reflector in the Arnager Graben, and mainly above the B reflector in the Rønne Graben (fig. 6). The grabens may, however have experienced some reversed rotation as a result of inversion (see below).

The strong thickness variation of unit 3 suggests that the depocenter in the Rønne Graben shifted somewhat to the north, during the Jurassic and possibly the Lower Cretaceous, and became somewhat limited in areal extent. The sedimentation was probably accompanied by synsedimentary faulting resulting in erosion of the structural highs from time to time, as reported from land areas (Gravesen et al 1982), reflected by the abundant hiati in the Mesozoic series found onshore. This is also indicated by internal minor unconformities. The sedimentation of the bulk of the Middle Jurassic to Upper Jurassic deposits was probably mainly restricted to graben areas. The general gradual increase in depositional area through Mesozoic seemed to become more rapid during the Early Cretaceous and the Late Cretaceous (cf. Gravesen et al 1982) and reaching a maximum with the Late Cretaceous transgression, which probably covered the entire area. Some erosion must have taken place during Early Cretaceous times, as indicated by the truncation of Jurassic and Triassic deposits below the $\mathrm{C}$ reflector representing Base Upper Cretaceous (or base Middle Barremian) on the Southern Bornholm High. The uplifted areas were probably the same structural highs as those of the the present, suggested by the present distribution of Precretaceous Mesozoic sediments (see f.ex. fig. 13). The Upper Cretaceous sediments are thought to have formed a more uniform sheet tapering in a northeasterly direction, due to the minor evidence of synsedimentary tectonics in the upper unit. Some minor discordancies do however represent some activity. These movements must be of a Late Cretaceous age and probably reflect Sub Herzynian tectonism. The sediments are truncating older sediments as also seen in Scania (Bergström et al 1982), northern Poland (Pozaryski \& BrochwitzLewinski 1978) and the Hanö Bay Basin (Kumpas 1979). Only a few stratigraphic stages of the Upper Cretaceous reached the northeastern periferal parts as seen in the Kristiansstad Basin in Scania, coinciding with the maximum Cretaceous transgression (Bergström et al 1982). This sheet is today interrupted by the structural highs and the inverted Rønne 
Graben and Arnager Graben, which is assumed to have been uplifted mainly in the early Tertiary as discussed below. The location of the northeastern edges of the Cretaceous cover sheet in the Hanö Bay Basin are governed by these later tectonic event indicated by the discordant relation at the base of the Quarternary (Kumpas 1979).

\section{Cenozoic}

The whole area is strongly influenced by inversion tectonic features which to a great extent overprints older tectonic features and thus disguise older events. It is expressed as an uplift of the Rønne Graben and the Arnager Graben and by reactivation of several faults by introduction of reverse fault movements. It gives rise to a fault controlled erosional limitation of the $\mathrm{C}$ reflector. The internal reflectors in the uppermost unit do not show major tectonic disturbancies, but are mainly parallel to the $\mathrm{C}$ reflector, except for a few minor lowangle unconformities. The uplift must therefore be later than the sedimentation of the deposits represented by both the $\mathrm{C}$ reflector and the internal reflectors of the upper unit 4 , which is interpreted as comprising sediments of mainly Cretaceous and Danian ages. As unit 4 is believed to be comparable to the sequence found on the Skurup high of southern Scania (cf. Bergström et al 1982), and the deformation is post- depositional, then a Tertiary inversion is the most likely. The inversion is therefore thought to be of Tertiary age, coinciding with the Laramide inversion of Northern Poland (Pozaryski and Brochwitz-Lewinski 1978). The minor internal discordancies are referred to the intra Senonian Sub-herzynian phase. The absence of the Upper Jurassic in the northern part of the Rønne Graben is probably also due to this inversion and Late Jurassic tectonic events need not be taken into consideration as previously proposed (Graversen et all 1982), although the area was affected by the activity at that time. This is explained by the fact that the $\mathrm{C}$ reflector is the only reflector to posses reverse faulting alone, in the Rønne Graben, where the youngest Jurassic sediments are found.

\section{Discussion on the tectonic development.}

Both the older and the younger reverse faults have a mainly WNW-ESE strike outside the Rønne Graben and the Arnager Graben. However a number of approximately N-S trending faults inside the Rønne Graben and both the bounding faults of the Rønne Graben and the Arnager Graben (which are essentially normal) have conspicuous reverse components as seen on the section shown in fig. 6. A hypothesis for the explanation of these directions is possible by using a simple stress model using a N-S compressive stress system (Alpine direction) similar to the system that prevailed during the initiation of the Rønne Graben as discussed above. The system is similar to the system that caused the uplift and erosion of the Polish Trough as discussed by Ziegler (1981). Compression resulted in the reversal of tensional faults, uplift and folding of sediments, according to Ziegler. This was accompanied by right-lateral fault movement in the compressive stress system.

Using right lateral fault movement, two cases may occur, when dealing with an en-echelon arranged fault system (fig. 14). A right-stepping system develop tensional "pull-apart" structures, ultimately producing pull-apart basins, whereas a left-stepping produce compressional features (Rodgers 1980). The tensional right-stepping system that existed during the initiation af the Rønne Graben was probably similar to that of the southern California as reported by Burchfiel \& Steward (1966) and Crowell (1974) though in a smaller scale. The Tertiary tectonic phase might have been similar to the left-stepping right lateral fault system supported by the above mentioned considerations by Ziegler.

The deformations can in both cases be expected to posses an orientation directly related to the regional stress system. The Tertiary deformation structures in the two grabens are seen to posses an orientation

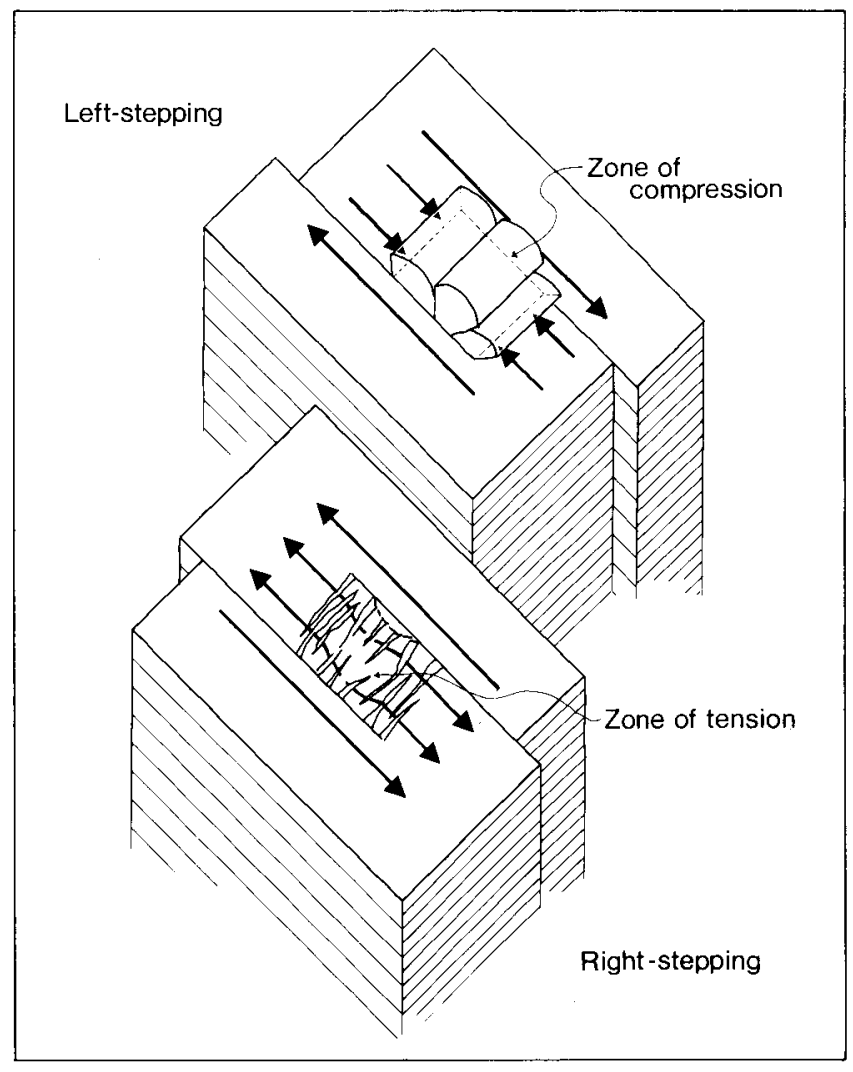

Fig. 14: Two settings are possible in an en-echelon wrench fault system, here depicted in a right lateral setting. (After Rodgers 1980). 
which points to a compressional stress perpendicular to the N-S compressional stress. This is explained by a confinement of deformation to the graben structures because the structural highs mainly have acted as rigid elements that only transmitted the deformational forces. The deformation has been comfined to older faults and the sediments inside the grabens. The Tertiary right-lateral fault system did thus have the opposite effect concerning the movement on the two above mentioned grabens, compared to the Late Carboniferous Early Permian stress system. The grabens have been subjected to compression instead of extension as before, both events as a result of differential right-lateral fault movement along a number of faults of essentially the same orientation, but with different movement-patterns (fig. 6 \& 2). The Laramide inversion is therefore not limited to the Caledonian deformation front as previously proposed (f.ex. Pozaryski and Brochwitz- Lewinski 1978). This hypothesis explains the occurence of the two different reverse fault directions and why the N-S striking faults are restricted to the grabens.

\section{Concluding remarks}

Many unpublished reports on seismic studies of this area have all proposed somewhat different views on the evolution of the area. The composition and variation of the sedimentary sequence have all shown some difference in composition and often presented audaceous degrees of detail. Fault patterns are in general similar, but details are even extremely different. These differences may probably be settled, when a few deep wells are drilled. The different interpretations may be regarded as of equal value until then. The key to the understanding of the development of the area is here believed to be the proper interpretation of the graben genesis and development,- especially the Rønne Graben. The development may be outlined by the stacking of three genetically different sedimentary basins. A basin existing prior to the initiation of the graben, the graben basin, and the post graben basin developing after the termination of graben tectonism. The first phase prior to graben faulting, is constituted by Unit 1, which is interpreted to represent Palaeozoic sediments. The second phase, where active down-faulting prevails during the development of the graben, is constituted by unit 2 and 3, which span Triassic (Permian ?) to Early Cretaceous (Early Barremian) ages. The post graben basin is represented by unit 4 , which span Late Barremian to Cenozoic ages. By contrast to typical graben delopments (c.f. the Central Graben area) this phase is strongly influenced by inversion tectonism. These phases coincides in time with the development of for instance the Central Graben area. 


\section{Acknowledgements}

I would like to thank all who guided and advised me in this work. First of all I thank Olaf Michelsen and Claus Andersen (Geological Survey of Denmark) for advise and for carefull reading of the manuscript. A special thanks is also given to Jens Christian Olsen (Danish Petroleum Exploration Consultants) for starting me on this project, and to Gunther Schönharting (University of Copenhagen), who guided me through my thesis study upon which this paper is based. Thanks is also given to all who helped in the praperation of manuscript and illustrations.

\section{Authors comment}

After this manuscript was send off for printing, a reprocessing of the seismic data by DANPEC (aps.) has revealed that an alternativ interpretation is more likely in the Rønne Graben. The Lower Paleozoic sediments continues according to these new data all the way through the Rønne Geaben. This means that unit 2 is of a Lower Palaeozoic age in the two northern thirds of fig. 2, - on fig. 6 the lower sequence in the Rønne Graben is equal Lower Palaeozoic, - fig. 8 shows extension of Lower Palaeozoic sediments, and fig. 7 and 9 has Lower Palaeozoic sediments as the lower unit. The error occurs north of the area, where the Lower Palaeozoic is thick, because a major WNW-ESE striking fault is concealed by multiples and sideswipe leads to erroneous interpretation. However, this possible misinterpretation is not believed to result in any error concerning the description of the general geological evolution. This paper is therefore believed to be of value anyway. 


\section{List of references}

Andersen, C., Olsen, J. C., Michelsen, O. and Nygaard, E. 1982: Structural outline and development. In Michelsen, O. (ed.): Geology of the Danish Central Graben. Danm. Geol. Unders., Ser. B, 8, pp. 9-26.

Andersen, O. B., Larsen, B. \& Platou, S. W. 1975: Gravity and Geological structures of the Fennoscandian Border zone in the Southern Baltic. Bull. Geol. Soc. of Denm. vol. 24 (1), pp. 45-55

Bergström, J., Holland, B., Larsson, K, Norling, E. \& Sivhed, U. 1982: Guide to excursions in Scania. Sveriges Geologiska Undersögningar Ser. Ca. No. 54 Uppsala.

Bjelm, L., Hartlen, J., Roshoff, K., Bennet, J. Bruch, H., Person, P. G. and Wadstein, P. 1977: Geotermisk energiutvinning i Skåne, slutrapport etapp 1, 2 \& 3. Tekniska Högskolan i Lund Sweden.

Bjerreskov M. \& Jørgensen, K. A. 1983: Late Wenlock graptolite- bearing tuffaceous sandstone from Bornholm Denmark. Bull. Geol. soc. of Denm., Vol. 31, pp. 129-149.

Burchfiel, B. C. \& Steward, J. H. 1966: "Pull-Apart" origin of the central segment of Death Valley California. Bull. geol. Soc. Am. Vol. 77 (4), pp. 439-441.

Bylund, S. 1974: Palaeomagnetism of dykes along the southern margin of the Baltic Shield. Geol. Fôrh. Stockholm. Vol. 96 pp. 231-235.

Crowell, J. C. 1974: Origin og the Late Cenozoic Basins in Southern California. In Tectonics \& Sedimentation. Soc. Econ. Pal. \& Min. Spec. Publ. No. 22 pp. 190-204.

Dadlez, R. 1974: Some geological problems of the Southern Baltic Basin Acta Geologica Polonica. Vol. 24, (1), pp. 261-275.

Dadlez, R. 1983: O koncepcji Wczesnopaleozoicznych wielkich ruchow przesuwczych wzdluz krawedzi plyty Laurentyjskiej i Baltyckiej. (On the concept of a major Early Palaeozoic wrench movement along the edges og Laurentian and Baltic Plates). Przegl. Geol., XXXI nr. 6.

Danmarks Geologiske Undersøgelser 1980: Hydrogeologisk kortlægning af Bornholm Amtskommune. Geol. Surv. of Denm.

Danish Underground Consortium 1974: Aeromagnetometric survey - Bornholm Area southern Baltic - Residual field intensity contour map 1:200.000. Gulf Oil Company of Denmark (unpublished)

Franke, D. 1967: Der erste Aufschluss im tieferen Palaeozoicum Norddeutschlands and seine Bedeutung für die Tectonische Gliederung Mitteleuropas. Jour. f. Geol. 1965 Bd. 1.

Gravesen, P. \& Bjerreskov, M. 1982: Guide to excursions in Bornholm - During 8th annual working meeting in Sweden and Denmark of project Tornquist - Southwest border of the East European Platform. IGCP Project No. 86 Geol. Surv. of Den. Copenhagen.

Gravesen, P., Rolle, F. \& Surlyk, F. 1982: Lithostratigraphy and sedimentary evolution of the Triassic, Jurassic, and Lower Cretaceous of Bornholm, Denmark, Danm. Geol. Unders. Ser. B no. 7.

Gry, H. 1969: Megaspores from the Jurassic of the Island of Bornholm, Denmark. Bull. Geol. Soc. of Denmark Vol. 19 (1), pp. 69-89.
Harding, T. P. 1982: Graben hydrocarbon plays and structural styles. Geol. en Mijn. Vol. 62 (1), pp. 3-23.

Kumpas, M. G. 1978: Distribution of sedimentary rocks in the Hanö bay and south of land. Acta Universitatis Stockholmiensis Stockholm Contributions in Geology. Vol. 31 (3), pp. 95-103.

Kumpas, M. G. 1979: Seismic Stratigraphy and Tectonics in the Hanö bay. Acta Universitatis Stockholmiensis Stockholm Contributions in Geology. Vol. 34 (4), pp. 35-168.

Kumpas, M. G. 1980: Mesozoic development of the Hanö bay Basin, southern Baltic. Geol. Fören. Stockh. forh. Vol. 101, pp. 359-362.

Kumpas, M. G. 1982: Seismic interpretation of the Christianø Horst, - Southern Baltic. Acta Universitatis Stocholmiensis Stockholm Contributions in Geology. Vol. 38, (4), pp. 4955.

Norling, E. \& Skoglund, R. 1977: Der Sudwestrand der Osteurropaischen Tafel In Bereich Schwedens. Zeitsch. f. Angewandte Geol. Vol. 23, (9), pp. 449-458.

Pozaryski, W. \& Brochwicz-Lewinski, W. 1978: On the Polish Trough. Geologie en Mijnbouw. Vol. 57 (4) pp. 545-557.

Pozaryski, W., Brochwicz-Lewinski, W. \& Jaskowiak-Schoeneichowa, M. 1979: The Geology of the Southern Baltic: Some Remarks. Bull. de L'Acad. de Polonaise des Sciensis. Vol. 26 (2), pp. 119-125.

Pozaryski, W., Brochwitz-Lewinsky, W. \& Tomczyk, H. 1982: Sur le caractere heterochronique da la Ligne TeisseyreTornquist, entre Europe centrale et orientale (On Heterochroneity of the Teisseyre-Tornquist Line, between Central and Eastern Europe). C. R. Acad. Sc. Paris, Vol. 295 ser. 2 (6), pp. 691-696.

Regnell, G. \& Ernheld Hede, J. 1960: The Lower Palaeozoic of Scania. The Silurian of Gotland. Guide to excursions. Int. Geol. Cong. XXI session Norden.

Rodgers. D. A. 1980: Analysis of pull-apart basin development produced by en echelon strike-slip faults. Spec. Publ. Int. Ass. Sediment. No. 4.

Rolle, F., Koch, J. -O., Frandsen, N. \& Surlyk, F. 1979: Jurassic environments in the Fennoscandian Border Zone. Symposium: Sedimentation Jurassique W. Europeen A. S. F. Publication speciale No I Com. Geol. no. 327.

Sharma, V. 1974: A note on seismic velocities of rock formations on Bornholm. Bul. Geol. Soc. Denm., vol. 23 pp. 191-196.

Troedson, G. T. 1932: Några Tektoniska ock stratigrafiska problem i Skåne. Geol. Fören. Forhandl. Vol 54 (2), pp. 220226.

Vejbæk, O. V. 1983: Interpretation of reflectionseismic data in the area around Bornholm between $5430 \mathrm{~N}, 5530 \mathrm{~S}$ and $140 \mathrm{E}, 160 \mathrm{E}$. Thesis study.

Ziegler, P. A. 1981: Evolution of Sedimentary Basins in North West europe. In Illing and Hobson (ed.): Petroleum Geology of the continental shelf of N. W. Europe. - Heyden \& Son Ltd. for Inst. of Petroleum London, pp. 3-39. 


\section{Appendix}

The primary data upon which this paper is based are two reflection seismic surveys shot by the Danish Underground Consortium in the years 1975 and 1976 (see fig. 15 for location). They are both 24 fold Common Depth Point (CDP) stack unmigrated with the majority displayed in $3 \mathrm{sec}$ and a few in $4 \mathrm{sec}$. The energysources were a 1760 and a 1460 cubic inch air-

Fig 15: The location of the two seismic surveys used in this study.

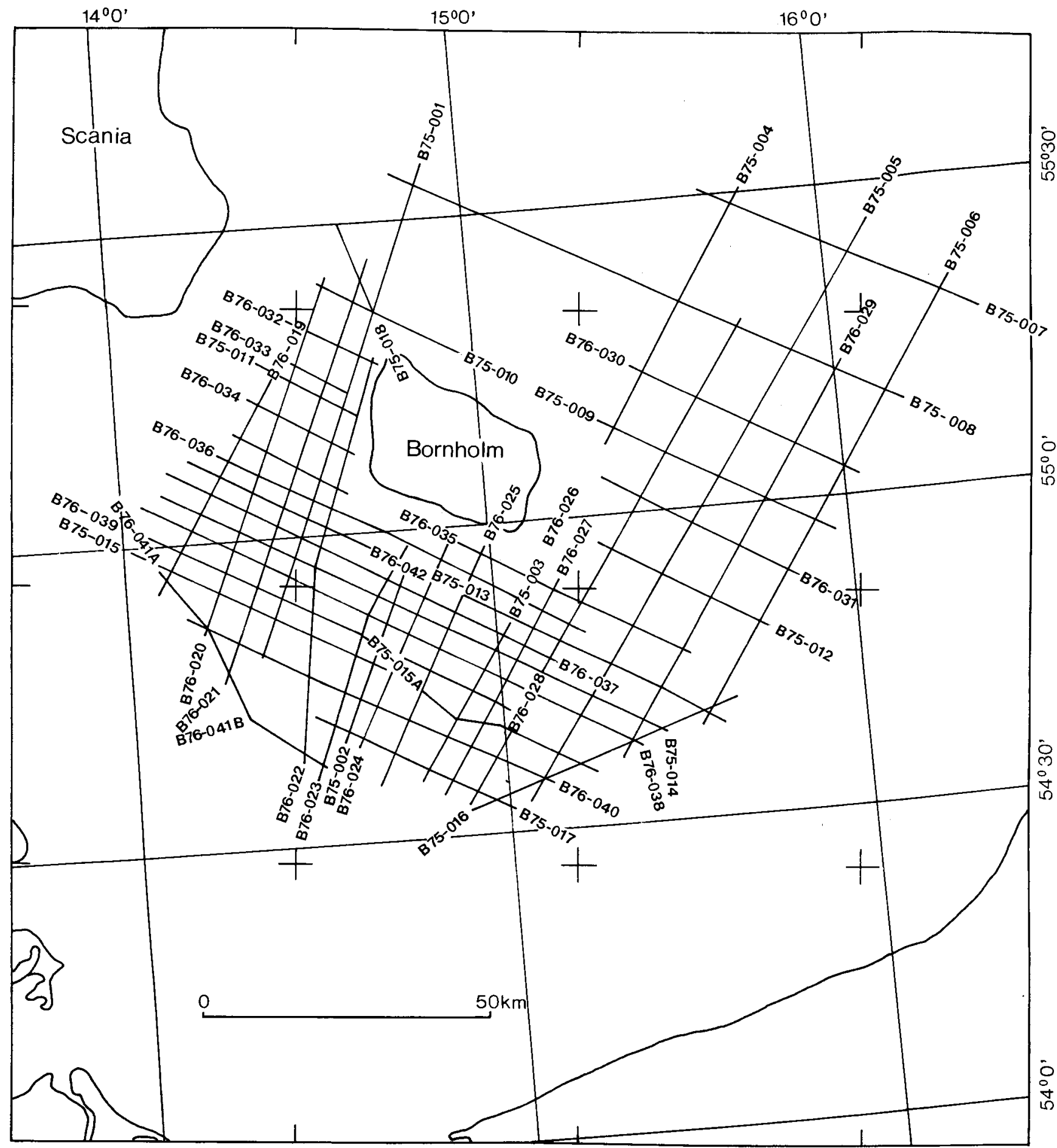


gun array in the 1975 and the 1976 surveys respectively. The data were recorded digitally with a sample rate of $4 \mathrm{msec}$, using a highpass filter og $62 \mathrm{~Hz}$. and a lowpass filter of $8 \mathrm{~Hz}$, - the lowpass filter was only applied in the 1976 data. A $2400 \mathrm{~m}$. cable with 48 geophone groups with $50 \mathrm{~m}$. spacing was used too produce a 24 fold CDP stack with a $200 \mathrm{~m}$. shotpoint interval. To achieve a good normall move out (NMO) correction deconvolution before stack was applied to the CDP gathers. The stacked data were deconvoluted with a filterlength of $120 \mathrm{msec}$. in the 1975 data and $272 \mathrm{msec}$. in the 1976 data. The filters were designed using data between 300 and $2990 \mathrm{msec}$. and 50 and $3000 \mathrm{msec}$. for the 1975 and the 1976 data respectively. Furthermore time variant frequency filters were used varying from $15-50 \mathrm{~Hz}$ bandpass at the top of the sections and ending up with $5-37 \mathrm{~Hz}$ bandpass at the bottom of the section in the 1975 data. These filters varied between $20-60 \mathrm{~Hz}$ bandpass and $8-38 \mathrm{~Hz}$ bandpass in the 1976 data. 
Plate 1

NEAR TOP BASEMENT

Time structure map

Eastern/Northern Limit of thick

$\sigma$ Fault, Box on down thrown side

100- Time depth contour. Values in mec.

约/le Area with Basement below $4000 \mathrm{msec}$.

V//, Area with Basement below $3000 \mathrm{msec}$. Interpreted by O. V. Vejbak 1983

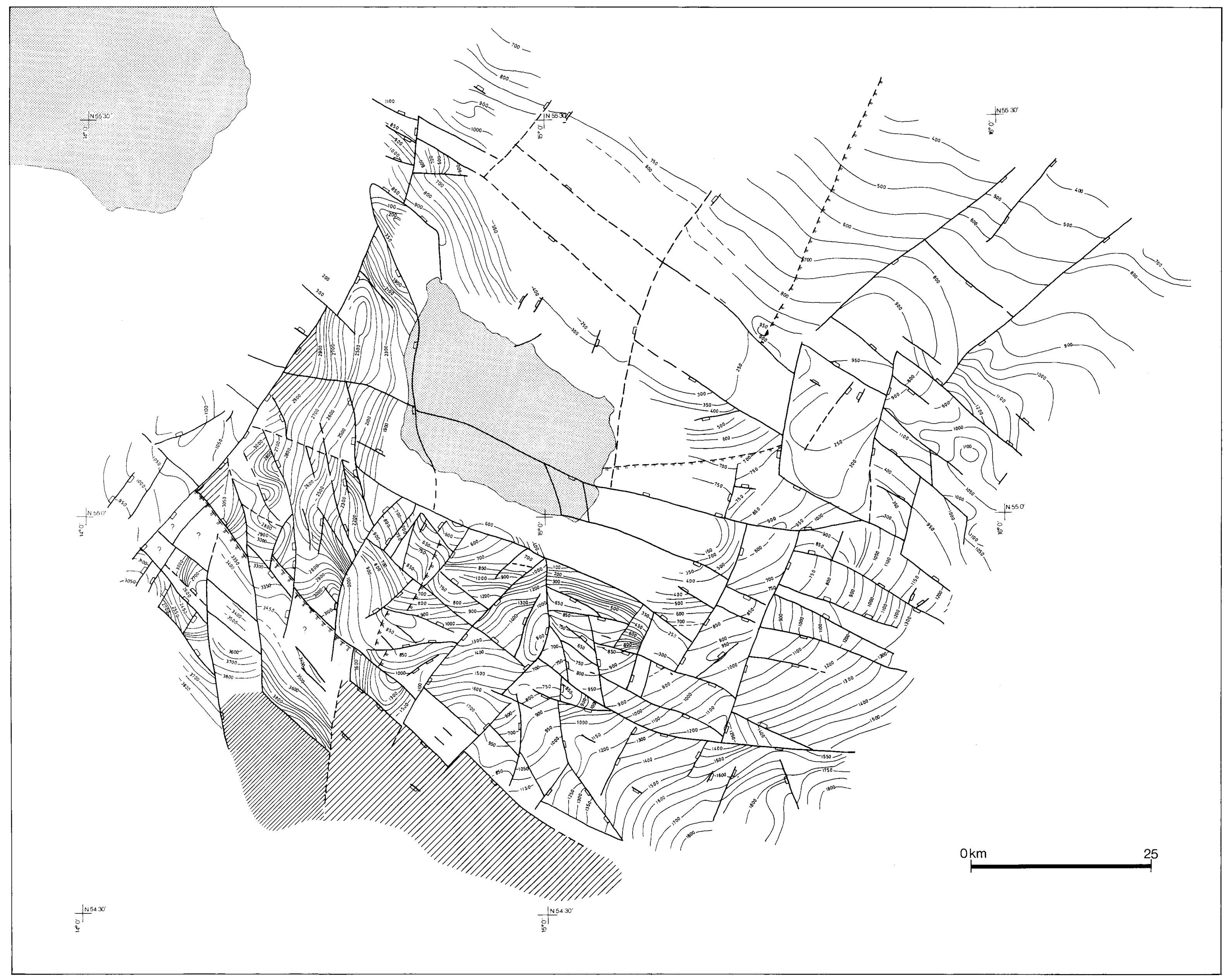


Plate 2

Aeromagnetometric interpretation map

(Aeromagnetometric survey by Compagnie Génerale de Géophysique 1974)
Flight height 500 ) Flight height $500 \mathrm{~m}$
Regional field correct

0 , 797 gamma/ $/ \mathrm{km}$ West to East

Is Isogamma curves, 5 gamma interval residual field intensity
Interpreted depth to basement, Values in $\mathrm{km}$.

$A_{x 14}$

$\mathrm{B}=$ Half gradient method
$\mathrm{C}=$ Equal gradient method. Depth in $\mathrm{km}$.

C $=$ Equal gradient method.
Interpeted by 0. V. Vejibek 1983

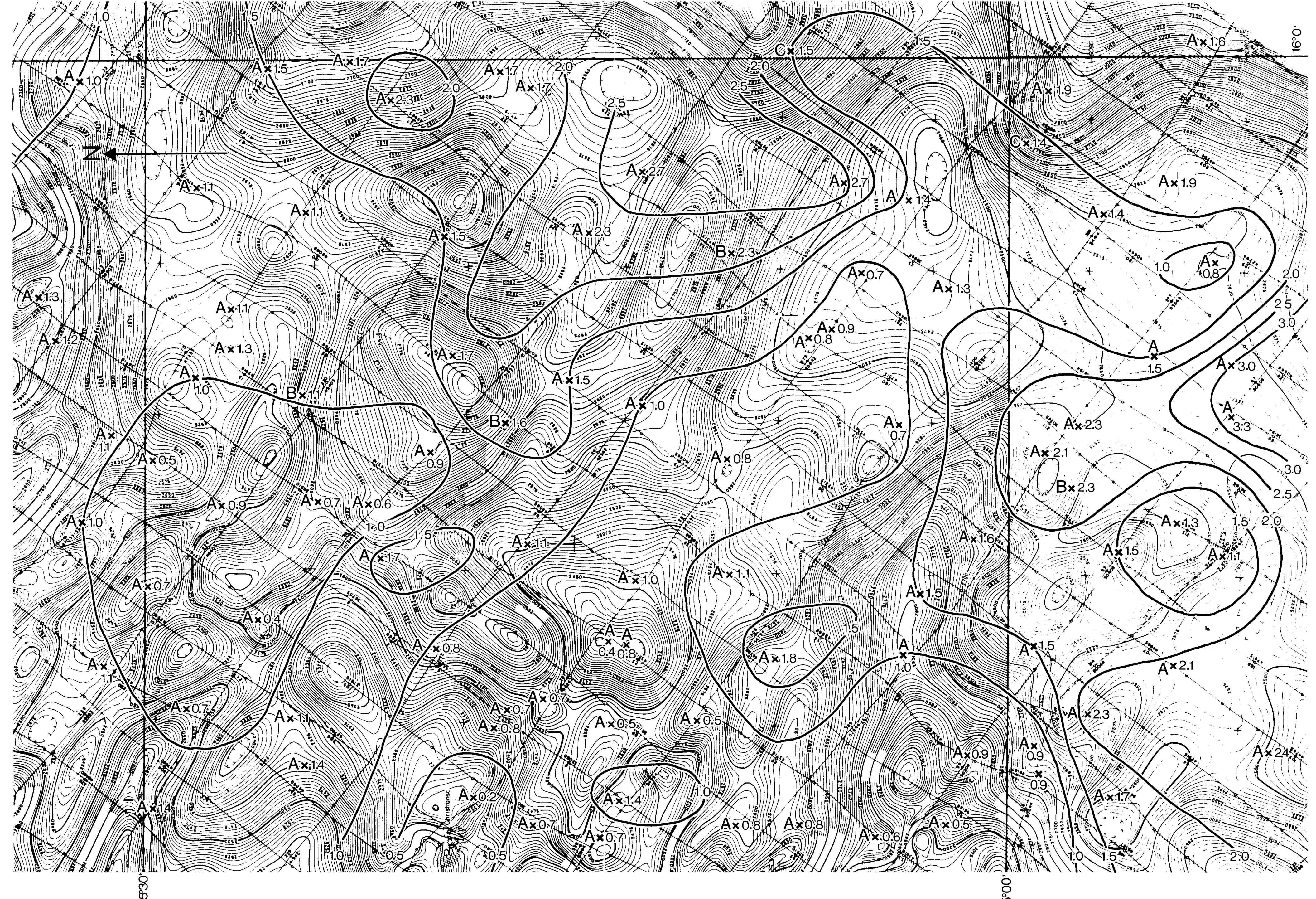


Plate 3

LOWER PALAEOZOIC/UNIT 1

Time isopack map

$\pi^{\pi}$ Lower Palaeozoic thin or absent $(<100 \mathrm{msec}$.)

$-30-$ Time isopack contour (Values in msec.)

$<$ Fault

Interpreted by O. V. Vejbex 1983

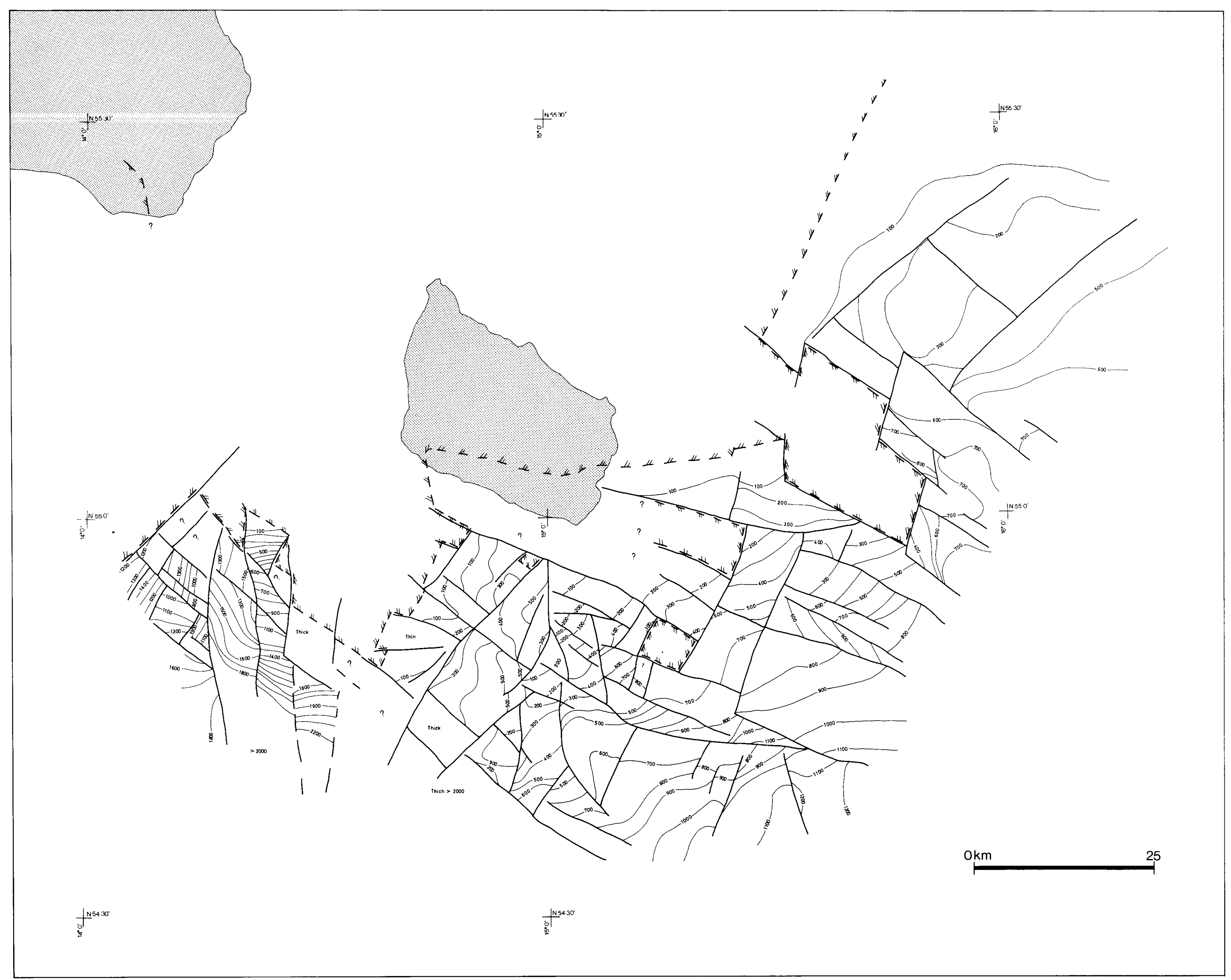


Plate 4

\section{REFLECTOR A}

Time structure map

$\sigma$ Fault, Box on down thrown side

Fault of transcurrent/unknown characte

${ }^{-500-}$ Time depth contour, Values in msec.

Horizon absent

Interpreted by O. V. Vejbæk 1983

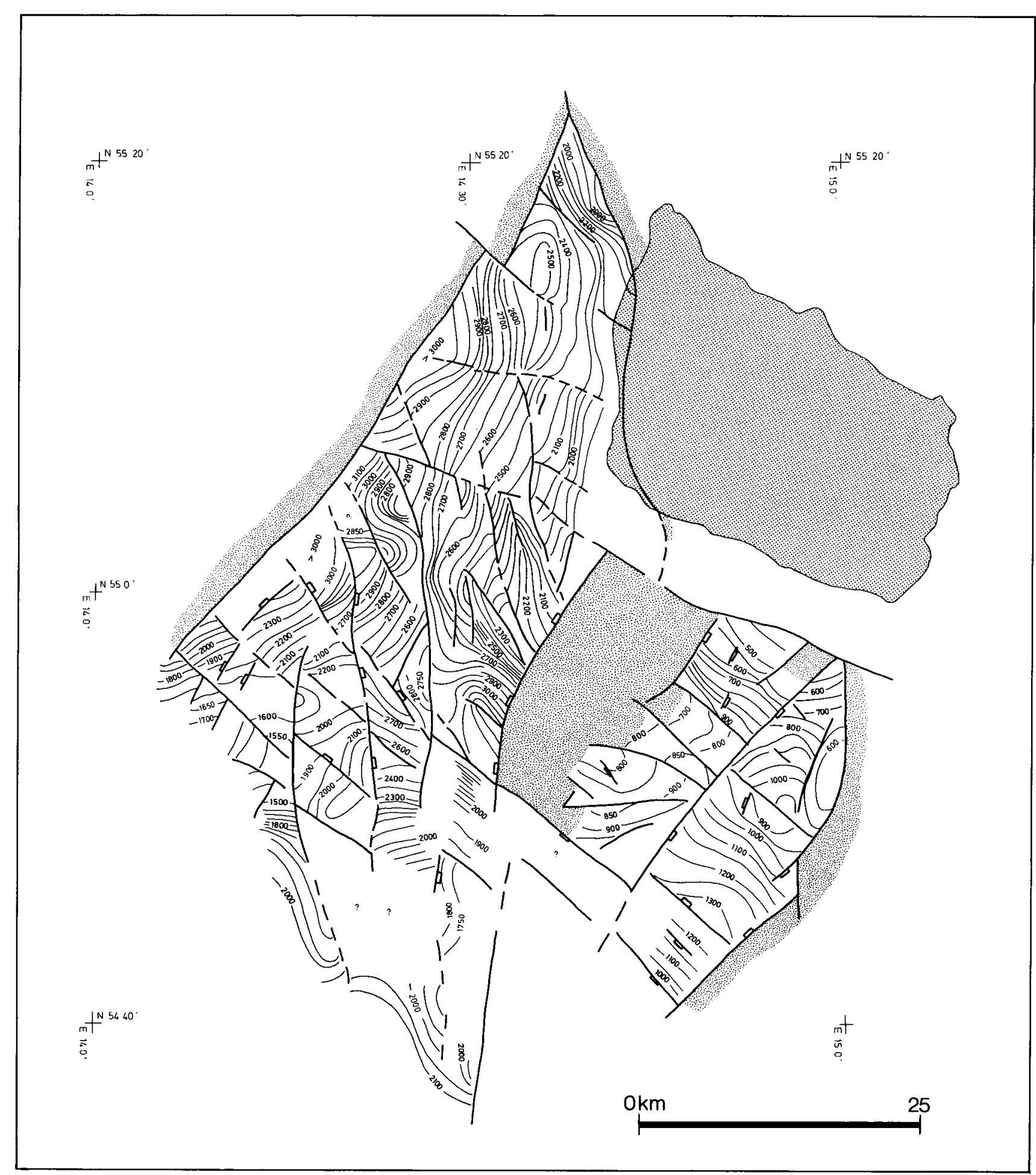


Plate 5

\section{REFLECTOR B}

Time structure map

150- Time depth contour, Values in msec.

$\sigma$ Fault, Box on down thrown side

Fault of transcurrent/unknown character Interpreted by O V Vejbæk 1983

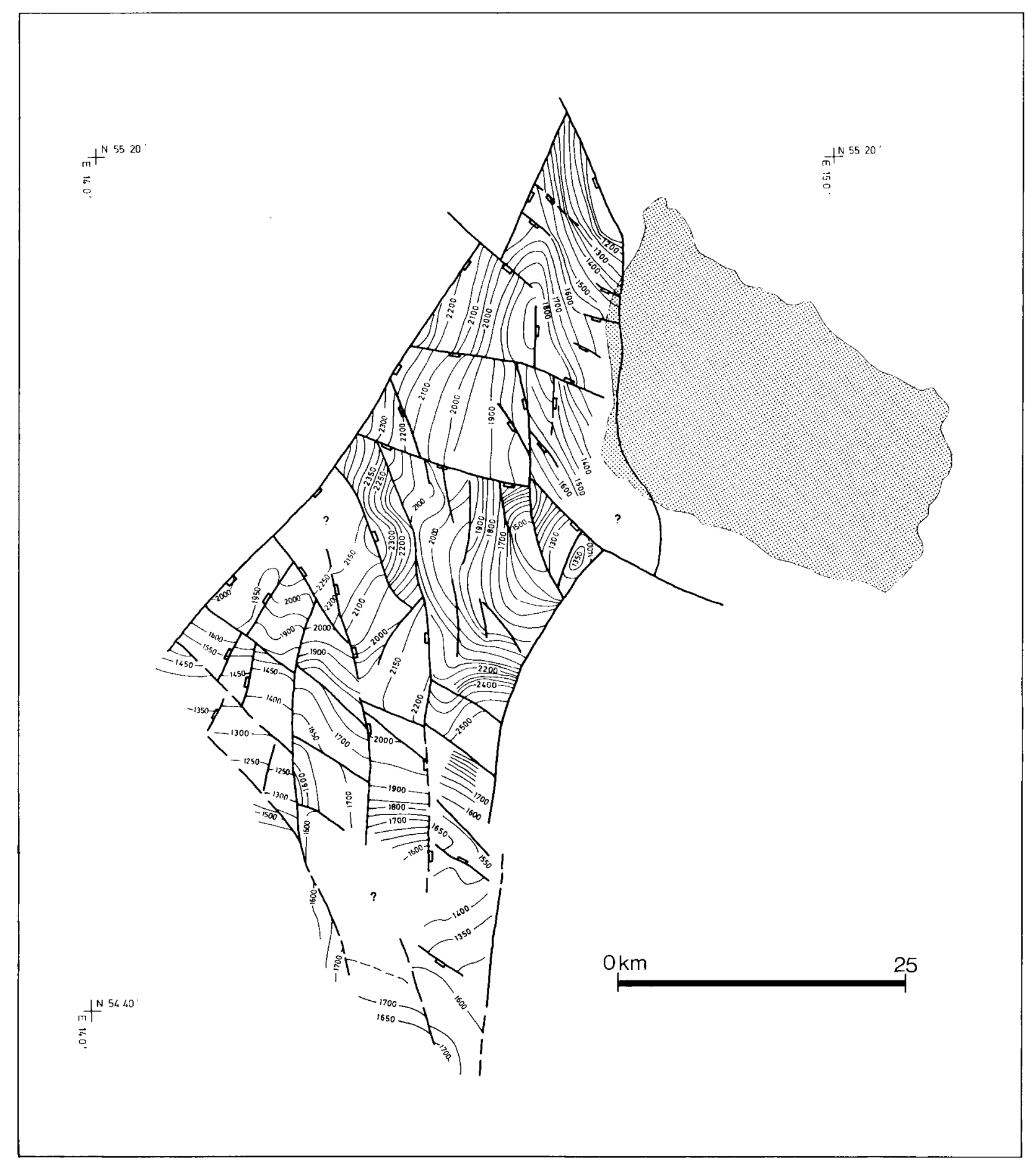


Plate 6

NEAR BASE UPPER CRETACEOUS

Time structure map

${ }_{-30}-$ Time depth contour, Values in msec.

$\sigma$ Normal Fault, Box on down thrown side

- Reserve Fault, Triangel showing dip of fault plane

Fault of transcurrent/unknown character

(2) Horizen eroded or absent

Interpreted by O. V. Vejbæk 1983

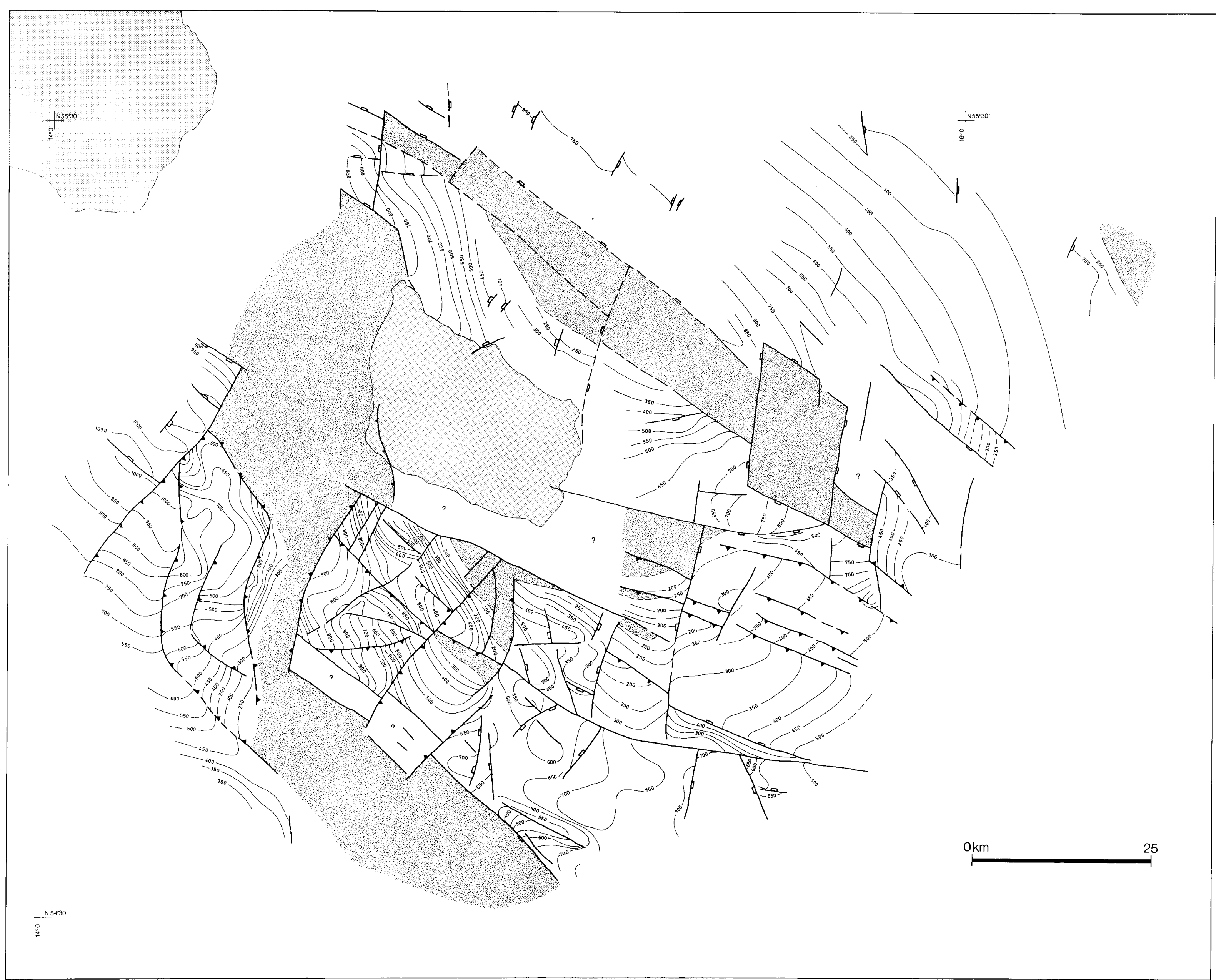


This book gives a most informative review of the seismic stratigraphy and tectonism of the sedimentary basins around Bornholm. The author demonstrates a continuous regionaltectonic pattern. The book will be an important source for further work

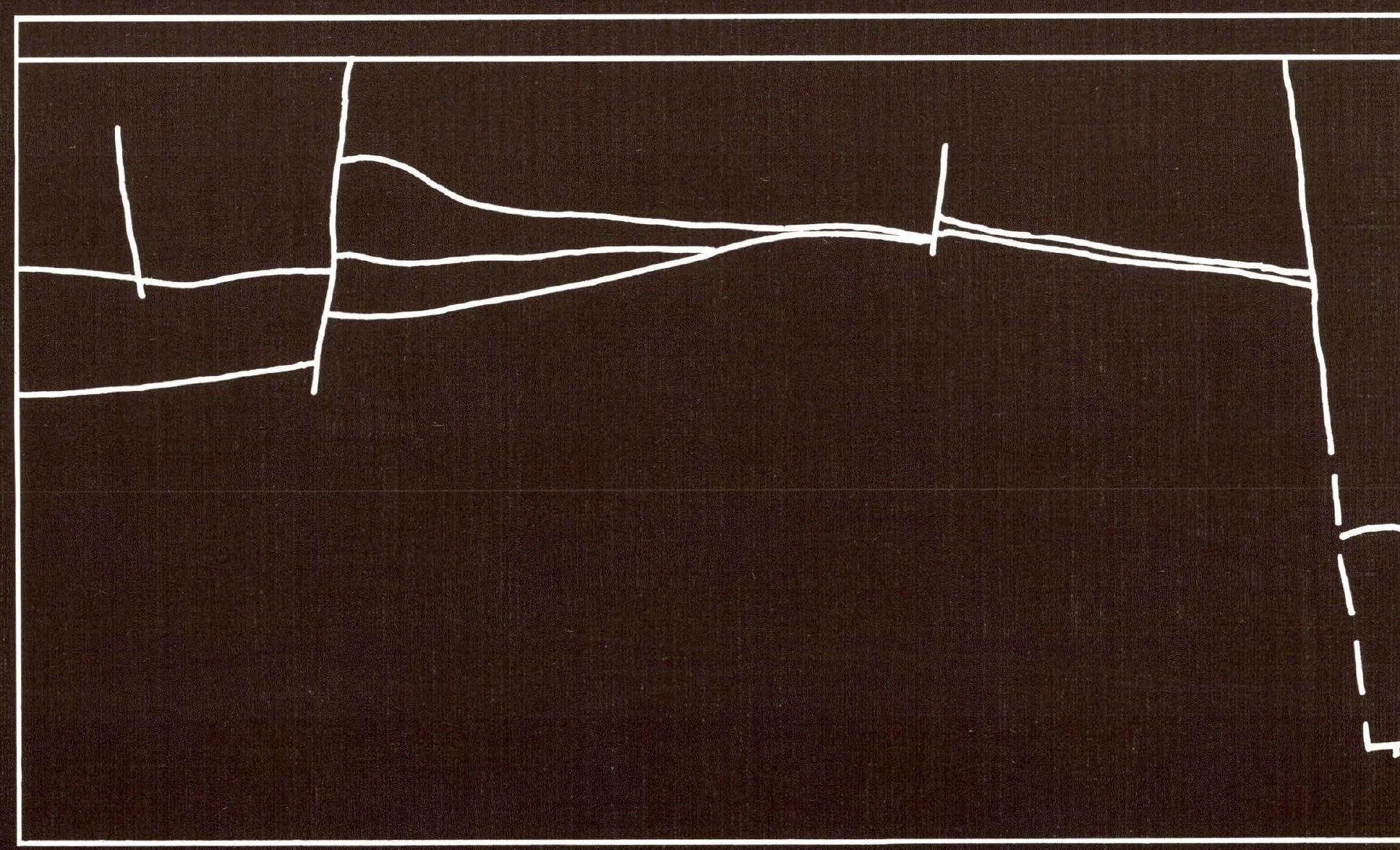

